\title{
Genotoxic Impurities in Pharmaceuticals
}

\author{
Abolghasem Jouyban ${ }^{1}$ and Hamed Parsa ${ }^{2}$ \\ ${ }^{1}$ Drug Applied Research Center and Faculty of Pharmacy, \\ ${ }^{2}$ Tuberculosis and Lung Disease Research Center, \\ Tabriz University of Medical Sciences, Tabriz,
}

Iran

\section{Introduction}

Genotoxic compounds induce genetic mutations and/or chromosomal rearrangements and can therefore act as carcinogenic compounds (McGovern and Jacobson-Kram, 2006). These compounds cause damage to DNA by different mechanisms such as alkylation or other interactions that can lead to mutation of the genetic codes. In general, chemists employ the terms "genotoxic" and "mutagenic" synonymously; however, there is a subtle distinction. Genotoxicity pertains to all types of DNA damage (including mutagenicity), whereas mutagenicity pertains specifically to mutation induction at the gene and chromosome levels. Thus, the term "genotoxic" is applied to agents that interact with DNA and/or its associated cellular components (e.g. the spindle apparatus) or enzymes (e.g. topoisomerases) (Dearfield et al., 2002; Robinson, 2010). Irrespective of the mechanism by which cancer is induced, it is now well agreed that it involves a change in the integrity or expression of genomic DNA. The majority of chemical carcinogens are capable of causing DNA damage, i.e., are "genotoxic" (Ashby, 1990). Moreover, a genotoxic compound also carries with it the carcinogenic effect which causes additional concern from the safety viewpoint.

Drug substances and their relative compounds such as impurities constitute an important group of genotoxic compounds. Thus, these compounds pose an additive concern to clinical subjects and patients (Müller et al., 2006). Considering the importance of this problem, the challenge for regulatory agencies is to form guidelines and standards for the identification and control of genotoxic compounds and their impurities especially in pharmaceuticals. In this article, genotoxicity profiles of the main group of genotoxic compounds are discussed. The article throws light on the challenges in analyzing and predicting for these groups and also deals with the different management problems of genotoxic impurities in pharmaceuticals.

\section{Guidelines}

\subsection{ICH guidelines}

The International Conference on Harmonization (ICH) of Technical Requirements for Registration of Pharmaceuticals for Human Use project represents the main group of guidelines with topics such as "Quality" topics and "Safety" topics. Quality topics relate to chemical and pharmaceutical quality assurance (stability testing, impurity testing, etc.) and 
safety topics deal with in vitro and in vivo pre-clinical studies (carcinogenicity testing, genotoxicity testing, etc.) (ICH, 2008).

The ICH initially published guidelines on impurities of drug substances and pharmaceutical products in the late 1990s. In the guidelines, genotoxicity tests have been defined as in vitro and in vivo tests designed for detecting compounds that induce genetic damage directly or indirectly (International Conference on Harmonization, 1997). The ICH quality guidelines $\mathrm{Q} 3 \mathrm{~A}(\mathrm{R})$ and $\mathrm{Q} 3 \mathrm{~B}(\mathrm{R})$ respectively address the topics of control of impurities in drug substances and degradants in pharmaceutical products, while the Q3C guideline deals with the residual solvents. However, several important issues have not been addressed in the guidelines, for example, the acceptable levels of impurities in drugs during development as well as the control of genotoxic impurities. Table 1 illustrates a series of thresholds described in $\mathrm{ICH} \mathrm{Q} 3 \mathrm{~A}(\mathrm{R})$ that trigger reporting, identification, and qualification requirements. Subsequently, Table 2 depicts the thresholds for reporting, identification, and qualification of impurities in new drug products (ICH, 2006; Jacobson-Kram and McGovern, 2007). In addition, two options for standard test battery for genotoxicity are available in the ICH S2 (R1) guideline (ICH, 2008):

\begin{tabular}{|c|c|c|}
\hline \multirow{2}{*}{ Thresholds } & \multicolumn{2}{|c|}{ Maximum daily dose } \\
\cline { 2 - 3 } & $\leq 2 \mathrm{~g} /$ day & $>2 \mathrm{~g} /$ day \\
\hline Reporting threshold & $0.05 \%$ & $0.03 \%$ \\
\hline Identification threshold & $\begin{array}{c}0.10 \% \text { or 1.0 mg per day intake } \\
\text { (whichever is lower) }\end{array}$ & $0.05 \%$ \\
\hline Qualification threshold & $\begin{array}{c}0.15 \% \text { or } 1.0 \text { mg per day intake } \\
\text { (whichever is lower) }\end{array}$ & $0.05 \%$ \\
\hline
\end{tabular}

Table 1. Threshold for APIs

\section{Option 1}

i. A test for gene mutation in bacteria;

ii. A cytogenetic test for chromosomal damage (the in vitro metaphase chromosome aberration test or in vitro micronucleus test), or an in vitro mouse lymphoma tk gene mutation assay;

iii. An in vivo test for genotoxicity, generally a test for chromosomal damage using rodent hematopoietic cells, either for micronuclei or for chromosomal aberrations in metaphase cells.

Option 2

i. A test for gene mutation in bacteria;

ii. An in vivo assessment of genotoxicity with two tissues, usually an assay for micronuclei using rodent hematopoietic cells and a second in vivo assay.

As stated by the ICH safety guidelines (S2A and S2B), "for compounds giving negative results, the completion of 3-test battery, perform and evaluate in accordance with current recommendations, will usually provide a sufficient level of safety to demonstrate the absence of genotoxic activity." Thus, any compound that produces a positive result in one or more assays in the standard battery has historically been regarded as genotoxic, which may require further testing for risk assessment (Müller et al., 2006). 


\begin{tabular}{|c|c|c|c|}
\hline $\begin{array}{l}\text { Maximum } \\
\text { Daily Dose }^{1}\end{array}$ & \begin{tabular}{|l} 
Reporting \\
Thresholds 2,3
\end{tabular} & Identification Thresholds 2,3 & Qualification Thresholds 2,3 \\
\hline$\leq 1 \mathrm{mg}$ & & $\begin{array}{l}1.0 \% \text { or } 5 \mu \mathrm{g} \text { TDI } \\
\text { whichever is lower }\end{array}$ & \\
\hline $1-10 \mathrm{mg}$ & & $\begin{array}{l}0.5 \% \text { or } 20 \mu \mathrm{g} \text { TDI } \\
\text { whichever is lower }\end{array}$ & \\
\hline $10-100 \mathrm{mg}$ & & & $\begin{array}{l}0.5 \% \text { or } 200 \mu \mathrm{g} \text { TDI } \\
\text { whichever is lower }\end{array}$ \\
\hline$<10 \mathrm{mg}$ & & & $\begin{array}{l}1.0 \% \text { or } 50 \mu \mathrm{g} \text { TDI } \\
\text { whichever is lower }\end{array}$ \\
\hline$>10 \mathrm{mg}-2 \mathrm{~g}$ & & $\begin{array}{l}0.2 \% \text { or } 2 \mathrm{mg} \text { TDI } \\
\text { whichever is lower }\end{array}$ & \\
\hline$>100 \mathrm{mg}-2 \mathrm{~g}$ & & & $\begin{array}{l}0.2 \% \text { or } 3 \mathrm{mg} \text { TDI } \\
\text { whichever is lower }\end{array}$ \\
\hline$\leq 1 \mathrm{~g}$ & $0.1 \%$ & & \\
\hline$>1 \mathrm{~g}$ & $0.05 \%$ & & \\
\hline$>2 \mathrm{~g}$ & & $0.1 \%$ & \\
\hline$>2 \mathrm{~g}$ & & & $0.15 \%$ \\
\hline
\end{tabular}

1 The amount of drug substance administered per day

${ }^{2}$ Thresholds for degradation products are expressed either as a percentage of the drug substance or as a total daily intake (TDI) of the degradation product. Lower thresholds can be appropriate if the degradation product is unusually toxic.

${ }^{3}$ Higher thresholds should be scientifically justified.

Table 2. Thresholds for degradation products in new drug products (Jacobson-Kram and McGovern, 2007)

\subsection{EMEA guideline}

The European Medicines Agency (EMEA) guideline describes a general framework and practical approaches on how to deal with genotoxic impurities in new active substances. According to the guideline "The toxicological assessment of genotoxic impurities and the determination of acceptable limits for such impurities in active substances is a difficult issue and not addressed in sufficient detail in the existing ICH Q3X guidance". In addition, the EMEA guideline proposed a toxicological concern (TTC) threshold value of $1.5 \mu \mathrm{g} /$ day intake of a genotoxic impurity which is considered to be associated with an acceptable risk (excess cancer risk of $<1$ in 100,000 over a lifetime) in most pharmaceuticals. Based on the TTC value, a permitted level of an active substance can be calculated concerning the expected daily dose. Higher limits might be justified under certain conditions such as short-term exposure periods (European Medicines Agency/ Committee for Medicinal Products (CHMP) for Human Use, 2006). In the context of this guideline, the classification of a compound (impurity) as genotoxic in general indicates that there are positive findings in established in vitro or in vivo genotoxicity tests with the focus on DNA reactive substances that have a potential for direct DNA damage. In the absence of such information, in vitro genotoxics are usually considered as presumptive in vivo mutagens and carcinogens (EMEA/CHMP, 2006). 
Based on the importance of the mechanism of action and the dose-response relationship in the assessment of genotoxic compounds, the EMEA guideline presents two classes of genotoxic compounds:

1. Genotoxic compounds with sufficient (experimental) evidence for a threshold-related mechanism,

2. Genotoxic compounds without sufficient (experimental) evidence for a thresholdrelated mechanism.

Those genotoxic compounds with sufficient evidence would be regulated according to the procedure as outlined for class 2 solvents in the "Q3C Note for Guidance on Impurities: Residual Solvents". For genotoxic compounds without sufficient evidence for a thresholdrelated mechanism, the guideline proposes a policy of controlling levels to "as low as reasonably practicable" (ALARP) principle, where avoiding is not possible.

On the other hand, this guideline provides no advice on acceptable TTCs for drugs during development, especially for trials of short duration (Jacobson-Kram and McGovern, 2007).

The pharmaceutical research and manufacturing association (PhRMA) has established a procedure for the testing, classification, qualification, toxicological risk assessment, and control of impurities processing genotoxic potential in pharmaceutical products. As most medicines are given for a limited period of time, this procedure proposes a staged TTC to adjust the limits for shorter exposure time during clinical trials (Table 3). Thus, the staged TTC can be used for genotoxic compounds having genotoxicity data that are normally not suitable for a quantitative risk assessment (Muller et al., 2006).

\begin{tabular}{|l|c|c|c|c|c|}
\hline & \multicolumn{5}{|c|}{ Duration of clinical trial exposure } \\
\cline { 2 - 6 } & $\begin{array}{c}\leq 1 \\
\text { month }\end{array}$ & $\begin{array}{c}>1-3 \\
\text { month }\end{array}$ & $\begin{array}{c}>3-6 \\
\text { month }\end{array}$ & $\begin{array}{c}>6-12 \\
\text { month }\end{array}$ & $\begin{array}{c}>12 \\
\text { month }\end{array}$ \\
\hline $\begin{array}{l}\text { Allowable Daily Intake } \\
(\mu \mathrm{g} / \text { day) for all phases of } \\
\text { development }\end{array}$ & 120 & 60 & 20 & 10 & 1.5 \\
\hline $\begin{array}{l}\text { Alternative maximum level of } \\
\text { allowable impurity based on } \\
\text { percentage of impurity in API }\end{array}$ & $0.5 \%$ & $0.5 \%$ & $0.5 \%$ & $0.5 \%$ & $0.5 \%$ \\
\hline
\end{tabular}

Table 3. PhRMA genotoxic impurity task force proposal - allowable daily intake ( $\mu \mathrm{g} /$ day) for genotoxic impurities during clinical development using the staged TTC approach

\section{Genotoxic impurities (Gls)}

\subsection{Sulfonates}

Sulfonate salts (Figure 1) are the most frequently used compounds in pharmaceutical developments. Salt formation is a useful technique for optimizing the physicochemical processing (formulation), biopharmaceutical or therapeutic properties of active pharmaceutical ingredients (APIs), and sulfonate salts are widely used for this purpose (Elder and Snodin, 2009). In addition to the advantages of processing, sulfonate salts possess some advantages over other salts such as producing higher melting point of the sulfonated API. This helps to enhance the stability and provide good solubility and may have certain in vivo advantages as well. For instance, in contrast to other salts of strong acids, mesylates do not have a tendency to form hydrates, which makes them an attractive 
salt form for secondary processing, especially wet granulation. Another benefit of these salts is their high melting point because APIs with low melting points often exhibit plastic deformation during processing which can cause both caking and aggregation. Typically, an increase in the melting point has an adverse effect on aqueous solubility owing to an increase in the crystal lattice energies. Sulfonic acid salts tend to be an exception to this rule, since they exhibit both high melting points as well as good solubility. In addition, as mentioned in the literature, the high solubility and high surface area of haloperidol mesylate result in enhanced dissolution rates $(<2 \mathrm{~min}$ in $\mathrm{pH} 2$ simulated gastric media), which are more rapid than the competing common ion formation (Elder and Snodin, 2009; Elder et al., 2010a).

On the other hand, sulfonic acids can react with low molecular weight alcohols such as methanol, ethanol, or isopropanol to form the corresponding sulfonate esters. In general, sulfonic acid esters are considered as potential alkylating agents that may exert genotoxic effects in bacterial and mammalian cell systems and possibly carcinogenic effects in vivo; thus, these compounds have raised safety concerns in recent times (Snodin, 2006; Teasdale et al., 2009).

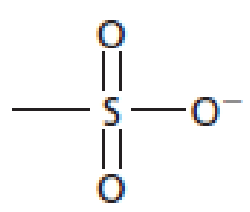

Mesyla

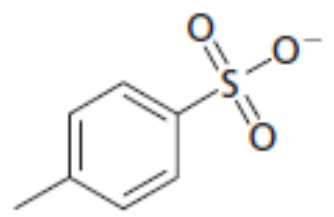

Tosylate

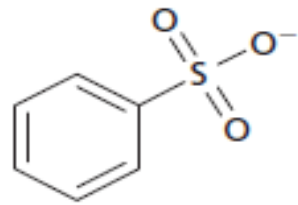

Besylate

Fig. 1. Structures of common sulfonate salts

\subsubsection{Genotoxicity profile}

Sulfonate impurities comprise the most investigated group of genotoxic impurities (GIs). Initially in 2007, sulfonate impurities raised major concern when over a period of three months (March to May 2007), several thousand HIV patients in Europe were exposed to Viracep $\mathrm{t}^{\mathrm{R}}$ (nelfinavir mesylate) tablets containing the contaminant ethyl methane sulfonate (EMS). However, the available in vitro and animal data indicated that the levels at which HIV patients were exposed to EMS (maximal dose of $0.055 \mathrm{mg} / \mathrm{kg} / \mathrm{d}$ ) did not induce any risk; nevertheless, any further level was of significant concern to their safety (Elder and Snodin, 2009). Since 2007 other drugs have been reported for contamination by sulfonate impurities, such as alkyl benzene sulfonates in amlodipine besylate (Raman et al., 2008), dimethyl sulfate (DMS) in pazopanib hydrochloride (Liu et al., 2009), EMS and methyl methane sulfonate (MMS) in imatinib mesylate (Ramakrishna et al., 2008), EMS in zugrastat (Schülé et al., 2010), alkyl sulfonates in flouroaryl-amine (Cimarosti et al., 2010), and ethyl besylate in UK-369,003-26, a novel PDE5 inhibitor (Hajikarimian et al., 2010).

EMS is a well-established genotoxic agent in this group which reacts with DNA producing alkylated (specifically ethylated) nucleotides. MMS, an analog of EMS, is a genotoxic compound both in vitro and in vivo. The international agency for research on cancer (IARC) has classified EMS and MMS in group 2B and 2A, respectively (Snodin, 2006; Gocke et al., 2009a). 
Gocke et al. (2009a) reviewed both in vivo and in vitro genotoxicity, carcinogenicity, general toxicity, and the effects on reproductive and embryo fetal development of EMS. They reported that the genotoxic effects induced by EMS were observed in viruses/phages, bacteria, fungi, plant, insect, and mammalian cells. In another study, the induction of gene mutations at the hprt locus and the induction of chromosomal damage were examined as evidenced by the formation of micronuclei in human lymphoblastoid cells. It was found that the lowest dose inducing a positive response was $1.40 \mu \mathrm{g} / \mathrm{ml}$, and a no observed effect level (NOEL) could be defined at $1.2 \mu \mathrm{g} / \mathrm{ml}$. Also, no toxicity was observed at doses up to 2.5 $\mu \mathrm{g} /$ plate. This observation is in strong contrast to the largely linear dose-response observed in the previous studies. As a result of in vivo assays for the induction of DNA damage, EMS is distributed rather uniformly over the body and induces similar levels of DNA damage in the various organs. Also, EMS is clastogenic in all test systems. The minimal dose of EMS applied in these studies was either $50 \mathrm{mg} / \mathrm{kg}$ or $100 \mathrm{mg} / \mathrm{kg}$. In the majority of studies the dose-response relationships appeared sub linear and a threshold below $50 \mathrm{mg} / \mathrm{kg}$ appeared possible. Gocke et al. (2009a) demonstrated that EMS in various gene mutation tests such as induction of hprt, lacZ, and dlb-1 mutations in mice was mutagenic. The carcinogenicity of EMS was confirmed in several animal models. In another study, three methanesulfonates and three benzenesulfonates were tested by micronucleus and Yeast deletion recombination (DEL) assays. It was observed that all six substances produced positive responses in the tests (Sobol et al., 2007).

\subsection{Alkyl halides and esters}

Owing to their electrophilic nature, alkylating agents can introduce lesions at nucleophilic centers of DNA. Drug salt formation includes strong acid/base interactions in the presence of alcohols, and can form impurities such as alkyl halides. As salt formation is a common method in drug formulation processes, alkyl halides exist as impurities in several drugs (Sobol et al., 2007; Elder et al., 2008a).

\subsubsection{Genotoxicity profile}

The nucleophilic attack mechanisms of alkylating compounds determine their reactivity against DNA. The SN1 mechanism leads to O-alkylation (O-6-methylguanine) which is mutagenic but not clastogenic, whereas the SN2 mechanism leads to N-methylation which is clastogenic and not mutagenic. In this group, it seems that bromo compounds are more reactive as compared to chloro compounds (Sobol et al., 2007; Snodin, 2010).

Various tests have been performed to study DNA damage and mutation in alkyl halides. In the Ames test, it was found that most alkyl halides, especially bromides, are Ames positive except 1-chloropropane, 1-chlorobutane, and neopentyl bromide. As chloro- and bromobenzene are not alkylating agents, these compounds are Ames-negative. In Yeast deletion recombination (DEL) and micronucleus assays, alkyl chlorides such as n-propyl chloride are found to be negative (Sobol et al., 2007; Snodin, 2010).

It was observed that alkyl chlorides in the NBP [4-( $p$ nitrobenzyl) pyridine] alkylation assay are not reactive and that allyl chloride has minimal activity. Although benzyl chloride is more active than other chloro compounds, ethyl, propyl, or butyl bromides have at least 1/40 MMS activity; however, allyl bromide appears to be more active (around one-eighth of the activity of MMS) (Sobol et al., 2007). 
As indicated by the in vivo test in rodent bioassay, these compounds are either noncarcinogens (1- chlorobutane, bromomethane) or low-potency carcinogens (chloroethane, bromoethane). According to in vivo tests, chloroethane and alkyl bromides seem to be nongenotoxic carcinogens rather than genotoxic carcinogens. Based on the available data, the United States environmental protection agency (USEPA), considers tert-butyl chloride to be a group D compound or "not classifiable as to human carcinogenicity" (Bercu et al., 2009; Snodin, 2010).

\subsection{Hydrazines}

Hydrazine is used as a medicine or as a starting compound for synthesizing some medicines. Hydrazine and some of its $N$-alkyl, $N$-aryl, and $N$-acyl analogues have been subjected to extensive toxicological evaluations. Hydrazines, hydrazides, and hydrazones have structural alerts for genotoxic potential and the metabolism increases their effects. Hydrazines adduct with DNA and the mechanism of adduction could include the formation of methyldiazanium ions or methyl free radicals. In addition, it seems that hydrazine reacts with endogenous formaldehyde to produce formaldehyde hydrazone. Subsequent to some other reactions, alkylating compounds like diazomethane as the genotoxic moiety are produced (Bercu et al., 2009; Snodin, 2010).

\subsubsection{Genotoxicity profile}

In vitro studies have shown genotoxic effects for three hydrazine derivatives (hydrazines, hydrazides, and hydrazones). These compounds induce gene mutations in human teratoma cells, mouse lymphoma cells, and in several strains of bacteria. Hydralazine (1hydrazinylphthalazine) and its hydrochloride salt are Ames-positive. In another study, 20 hydrazine-derivatives were found to induce a direct DNA damage in Escherichia coli and 16 of them (80\%) were Ames positive as well (Flora et al., 1984; Agency for Toxic Substance and Disease Registry, 1997; Snodin, 2010).

Although it was seen that hydrazine did not induce unscheduled DNA synthesis in mouse sperm cells, in vivo studies on the genotoxicity of hydrazines have largely produced positive results. In addition, it was observed that 1, 2-dimethylhydrazine failed to induce micronuclei in rat bone marrow cells, while this effect had been observed in mouse bone marrow cells (Agency for Toxic Substance and Disease Registry, 1997).

The non-carcinogenic effects of hydrazine were also evaluated; however, it was found that hydrazine, methyl hydrazine, 1,1- and 1,2-dimethylhydrazine, and other analogues are carcinogenic in rodents and possibly in human. In addition, it was seen that hydrazine derivatives like hydralazine and its hydrochloride salt were tumorigenic in rodents. It should be mentioned that the clinical use of hydralazine hydrochloride for several years has shown no evidence for carcinogenicity (Flora et al., 1984; Bercu et al., 2009; Snodin, 2010).

\subsection{Epoxides}

Epoxides are considered as electrophilic compounds owing to the strained epoxide ring. These alkylating agents directly react with DNA. Alkene oxides are more reactive than arene oxides and symmetrically substituted epoxides are less reactive than asymmetrically substituted compounds. Some examples for APIs with epoxide impurities are betamethasone acetate, atenolol, and some herbal remedies. Carbamazepine, cyproheptadine, and protriptyline have stable epoxide metabolites. In addition, phenytoin, 
lamotrigine, amitryptiline, and diclofenac tend to form reactive arene oxide metabolic intermediates (Flora et al., 1984; Elder et al., 2010b; Snodin, 2010).

The metabolism of epoxides mainly involves epoxide hydrolase $(\mathrm{EH})$ and glutathione $S$ transferase (GST), which leads to either detoxification or production of epoxides. These pathways play a key role in the genotoxic action of epoxides (Snodin, 2010).

\subsubsection{Genotoxicity profile}

As indicated in in vitro studies, epoxides are genotoxic in bacterial reverse mutation assays; however, other studies have shown different results. Hude et al. (1990) reported that 12/51 epoxides were nongenotoxic in the Ames Salmonella assay. In this study, 51 epoxides were assessed with the SOS-Chromo test using Escherichia coli PQ37 followed by a comparison with the results of the Ames test. All compounds were tested with and without S9 mixture up to cytotoxicity. In tests without S9 mixture the SOS-repair induction of each experiment was controlled by the response to 4-nitroquinoline-N-oxide, and in tests with S9 mixture, it was controlled with benzo[a]pyrene. In the Ames test, 20 epoxides were tested for mutagenic activity with the Salmonella typhimurium strains TA100, TA1535, TA98, and TA1537. By comparing the results of the Ames test and the SOS-Chromo test, it was found that among 51 epoxide-bearing chemicals 39 induced base-pair mutations in at least one Salmonella strain.

Wade et al. (1978) studied the mutagenicity of 17 aliphatic epoxides using the specially constructed mutants of Salmonella typhimurium that were developed by Ames. It was found that all the compounds in the study, with the exception of 2-methyl-3,3,3-trichloropropylene oxide, cis-stilbene oxide, and cyclohexene oxide that were mutagenic in strain TA100 were also mutagenic, but-with reduced sensitivity, in the second strain TA1535. However, none of the epoxides in this study were found to be mutagenic in strains TA1537 and TA98 which detect frame-shift mutagens. The results indicate that the monosubstituted epoxides are the most potent mutagens and that the addition of a single methyl group to the oxirane ring could reduce or eliminate mutagenicity.

Glatt et al. (1983) investigated 35 epoxides for mutagenicity, using reversion of hisSalmonella typhimurium TA98 and TA100 as the biological end-point. The results obtained were negative with the antibiotics oleandomycin, anticapsin and asperlin, the cardiotonic drug resibufogenin, the widely used parasympatholytic drugs butylscopolamine and scopolamine, the sedatives valtratum, didovaltratum and acevaltratum, the tranquilizer oxanamide as well as the drug metabolites carbamazepine 10,11-oxide and diethylstilbestrol $\alpha$ and $\beta$ oxide. It was found that among the drugs and drug metabolites, only the cytostatic ethoglucide was markedly mutagenic. Three barbiturate epoxides showed very weak mutagenicity only at extremely high concentrations such that the effects were probably of low practical relevance.

Later, the role of metabolism was also examined. For example, in vitro studies in rat-liver S9 fractions which contain both microsomal and cytosolic detoxifying enzymes, such as $\mathrm{EH}$ and GST showed a decrease of bacterial genotoxicity (Flora et al., 1984).

In vivo rodent bioassays on epoxides are not always positive and several epoxides are carcinogenic only at the point of administration. For example, it was found that when given by oral gavage, both ethylene oxide and propylene oxide caused late-onset tumors only in the rat fore-stomach. Again, when administered by inhalation, propylene oxide is a nasal carcinogen. On the other hand, in vivo studies in rat have shown that carbamazepine-10, 11- 
epoxide have the potential to initiate cellular damage if not adequately detoxified via conjugation with glutathione (Snodin, 2010).

It was observed that owing to the role of metabolism, epoxides that are formed in vivo, such as those generated by epoxidation of alkenes and arenes, have a greater potential to cause adverse effects than preformed epoxides. This is because they are often produced at close proximity to their site of action and can thus reach their target quite readily. Therefore, this mechanism can explain the limited evidence of animal carcinogenicity tests for some epoxide compounds (Flora et al., 1984).

\subsection{Aromatic compounds}

Aromatic compounds involve various impurities; some impurities, such as fentanyl impurities, tremogenic impurities, p-nitrophenol (PNP) that have aromatic structure and aromatic amines will be discussed in this section.

\subsubsection{Aromatic amines}

Primary and secondary aromatic amines (generally after metabolism) generate an electrophilic species and thus produce a positive result in the Ames test when S9 mixture exists. 2, 4-Diaminotoluene, 2, 4-diaminoethylbenzene and a few amines containing a nitrogroup are direct mutagens. According to the in vivo carcinogenicity test, Ames positive compounds produce positive results, although $p$-anisidine and $p$-chloroaniline are noncarcinogenic in rodent bioassays (Snodin, 2010).

\subsection{2 p-Nitrophenol}

This synthetic chemical possesses fungicidal activity and is used as a starting material for the synthesis of some drugs. PNP and other substituted nitro benzenes after reduction produce arylhydroxylamines or hydroxamic esters which contain electrophilic nitrogen atoms. Thus, the electrophilic atoms might show genotoxic property for these compounds (Eichenbaum et al., 2009).

It should be mentioned that negative results were obtained for Ames tests with the various strains of Salmonella typhimurium in the absence and presence of metabolic activation with rat liver S9. Another in vitro test, the hprt mutation test in Chinese hamster ovary $(\mathrm{CHO})$ cells presented the same result as the Ames test for PNP. However, it was seen that PNP could induce chromosomal aberrations in mammalian cells, particularly in the presence of metabolic activation. Also, PNP was negative in the bone marrow micronucleus assay in mice at doses ranging from little toxicity to the maximum tolerated dose. In addition, PNP was cytotoxic to the bone marrow of male mice at tested doses (Eichenbaum et al., 2009).

\subsubsection{Fentanyl impurities}

The forced degradation of fentanyl produced seven aromatic degradants. Among these, propionanilide (PRP), N-phenyl-1-(2-phenylethyl)-piperidin-4-amine (PPA), 1-phenethyl1H-pyridin-2-one (1-PPO), fentanyl N-oxide, and 1-styryl-1H-pyridin-2-one (1-SPO) possibly indicate safety concerns. PPA was suggested as a potential genotoxic compound and the DNA damage in unscheduled DNA synthesis (UDS); the results were positive for PRP when in vitro rat hepatocytes were checked. In the ACD/Tox suite, 1-PPO and 1-SPO were identified as Ames hazards. These compounds were also predicted to have higher probabilities of being Ames positive (Garg et al., 2010). 


\subsubsection{Tremogenic impurities}

Tremogenic impurities comprise another sub-class of highly toxic impurities in APIs. Two pharmacopoeial APIs are known to have the potential to be contaminated with tremogenic impurities; pethidine and paroxetine (3-[(1, 3-benzodioxol-5-yloxy) methyl]-4-(4fluorophenyl) piperidine). Pethidine can contain trace amounts of 1-methyl-4- phenyl-1, 2, 3, 6-tetrahydropyridine (MPTP) derived from the hydrolytic degradation of side chain. 4-(4Fluorophenyl)-1-methyl-1,2,3,6-tetrahydropyridine (FMTP) can be a potential reactant/intermediate in the synthesis of paroxetine. Owing to their toxicity to cells in the Substantia nigra, these highly potent impurities can induce Parkinsonism in humans. Thus, these compounds are known toxic impurities; however their genotoxicity remains unclear (Borman et al., 2008).

\section{6 $\beta$-lactam related impurities}

The following two impurities relate to the well known antibiotics cefotaxime and piperacillin.

\subsubsection{Dimeric impurity of cefotaxime}

The manufacturing and storage processes of cefotaxime produce various impurities such as dimeric impurity (Figure 2).<smiles>CO/N=C(/C(=O)N[C@H]1C(=O)N2C(C(=O)O)=C(CNc3nc(C(=O)N[C@H]4C(=O)N5C(C(=O)O)=C(COC(C)=O)CS[C@H]45)cs3)CS[C@H]12)c1csc(N)n1</smiles>

Fig. 2. Structure of the dimeric impurity of cefotaxime

The results of the mutagenesis assay indicate that the dimeric impurity is nonmutagenic to any test strains used in the presence and absence of S9 fraction. The results of the in vitro chromosomal assay show some chromosomal aberrations in cultured mammalian cells up to the maximum recommended concentration of $45 \mathrm{mg}$ per culture, and no clastogenicity in mammalian cells in vitro (Agarwal et al., 2004).

\subsubsection{Piperacillin impurity-A}

The piperacillin impurity-A is a prominent degradation product of piperacillin that appears during manufacturing and storage processes (Figure 3 ).

In all the strains of S. typhimurium; TA 97a, TA 98, TA 100, TA 102, and TA 1535, piperacillin impurity in the presence and absence of metabolic activation was found to be nonmutagenic. Also, in vitro chromosomal aberration assay did not reveal any significant alterations. It is found that piperacillin impurity-A up to $5 \mathrm{mg} / \mathrm{ml}$ is nonclastogenic to $\mathrm{CHO}$ cell lines in the presence and absence of metabolic activation (Vijayan et al., 2007). 


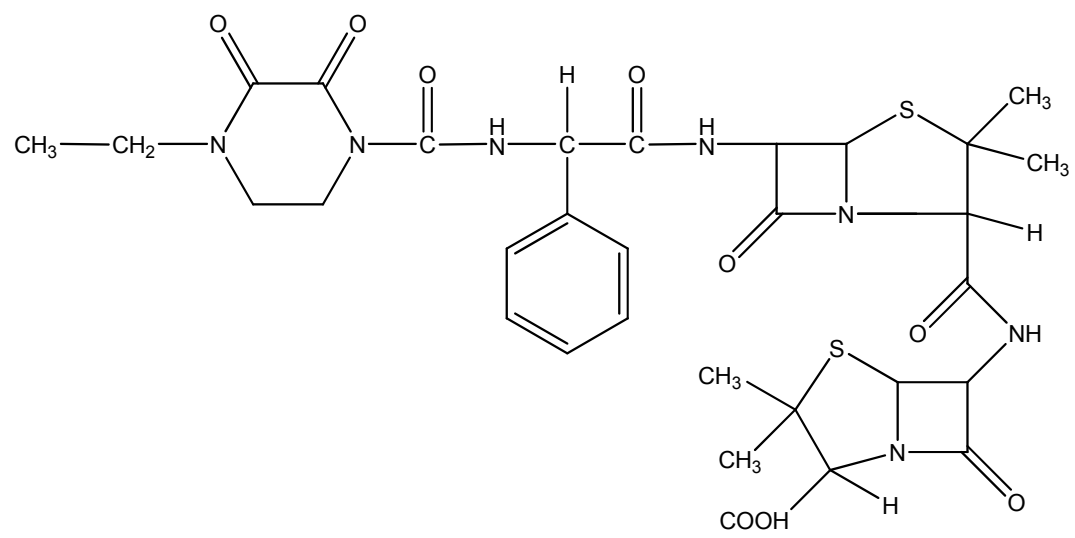

Fig. 3. Structure of piperacillin impurity-A

\section{Analytical approaches}

As discussed above, GIs possess unwanted effects and their contamination levels should be controlled. To achieve this, pharmaceutical R\&D should employ robust and sensitive analytical methods for supporting drug development and monitoring the levels of GIs. In addition, analytical methods that are capable of measuring trace GIs must be employed to monitor the outcome of GIs during chemical synthesis. In recent years, manufacturers have developed sensitive methods for analyzing various GIs. In this context, conventional HPLC/UV methods are the first option for GIs analysis; however, these methods are often inadequate for the accurate determination of analytes at trace levels, depending on the properties of the analytes and sample matrices. Some of the challenges in the analytical determination of GIs in pharmaceuticals at trace levels include the diverse structural types of GIs, the unstable or chemically reactive nature of GIs, and an extremely high level of API as contaminant (Bai et al., 2010; Liu et al., 2010).

\subsection{HPLC methods}

In general, non-volatile GIs are analyzed by HPLC separation techniques, among which reversed phase HPLC (RPLC) is the most widely used separation mode (Elder et al., 2008a; Liu et al., 2010). A simple isocratic RPLC method has been employed for the determination of four genotoxic alkyl benzenesulfonates (ABSs) viz. methyl, ethyl, n-propyl, and isopropyl benzenesulfonates (MBS, EBS, NPBS, and IPBS) in amlodipine besylate (ADB). The RPLC is also applicable for sulfonate impurities with phenyl moiety such as methyl (MTs), ethyl (ETs) and isopropyl tosylates (ITs), methyl (MBs), ethyl (EBs), butyl (BBs) and isopropyl besylates (IBs) (Raman et al., 2008).

Epoxides/hydroperoxides were analyzed using HPLC, and simple RPLC methods employing direct analysis (no sample preparation) were used for some of them. Yasueda et al. (2004) described an HPLC method for the determination of loteprednol impurities including a minor photolytic epoxide degradation product. Lacroix et al. (1992) reported an HPLC method for the determination of related substances, including the epoxide impurity of nadalol. A rapid resolution HPLC method was used for separating and quantifying the related impurities of atorvastatin, including two epoxide impurities atorvastatin epoxy 
dihydroxy and atorvastatin epoxy diketone. The limit of detection (LOD) and limit of quantitation (LOQ) for atorvastatin epoxy dihydroxy and atorvastatin epoxy diketone were 0.025 and $0.075 \mathrm{~g} / \mathrm{ml}$, and 0.026 and $0.077 \mathrm{~g} / \mathrm{ml}$, respectively (Petkovska et al., 2008). Kong et al. (2001) determined two epoxide terpenoid impurities (actein and 27-deoxyactein) in a traditional Chinese herbal preparation (Cimicifuga foetida L.). Subsequently, they compared the HPLC results with evaporative light scattering detection (ELSD) with UV detection and found that the ELSD was significantly more sensitive. Sample pretreatment was performed prior to analysis owing to the complexity of the matrix. For the two epoxides the on-column sensitivity using UV detection was found to be 606 and $880 \mathrm{ng}$, respectively, whereas the sensitivity using ELSD was 40 and $33 \mathrm{ng}$, respectively. Using the optimized extraction procedure (methanol/water, $80 / 20 \mathrm{v} / \mathrm{v}$ ) the levels of the two analytes were detected to be $3.44 \pm 0.02 \%$ and $1.42 \pm 0.01 \%$, respectively.

A more common method for the analysis of alkylating impurities is by RPLC and MS detection; however, HPLC/UV methods are also carried out successfully for alkylating impurities. Valvo et al. (1997) reported an HPLC/UV method for the separation of 13 impurities of verapamil; this method is claimed to be superior to both the existing pharmacopoeial methods for verapamil. Using this method, the LOD and LOQ were found to be $0.01 \%(0.05 \mu \mathrm{g} / \mathrm{ml})$ and $0.02 \%(1.0 \mu \mathrm{g} / \mathrm{ml})$, respectively. Also, the method was found to be sensitive to $\mathrm{pH}$ and mobile phase composition; however, it was in contrast to the findings of previous studies insensitive to stationary phase changes.

Hydrophilic interaction liquid chromatography (HILIC) seems complementary to RPLC for the retention and separation of small molecule polar analytes, and has thus gained increasing attention recently. Good retention can be achieved for more polar analytes, which is not possible on RPLC columns. In the hydrazine group, the HILIC method was used in addition to the HPLC/UV and HPLC/MS methods (Elder et al., 2010c; Liu et al., 2010). An Indian research group reported the development and validation of a stability indicating HPLC method for the determination of the anti-tuberculosis drug, rizatriptan, and its degradation products, including a hydrazone impurity (Rao et al., 2006). Hmelnickis et al. (2008) used an HILIC method with different polar stationary phases (silica, cyano, amino, and the zwitterionic sulfobetaine) to separate six polar impurities, including 1,1,1-trimethylhydrazinium bromide, and demonstrated that HILIC was a useful alternative to reverse phase or ion chromatography (IC). Elder et al. (2010c) reported a table summarizing the various HPLC methods that were used in the literature for a wide range of drugs (Table 4).

\begin{tabular}{|l|l|l|}
\hline $\begin{array}{l}\text { Active Potential } \\
\text { Ingredient (API) }\end{array}$ & Impurities & Method details \\
\hline Allopurinol & Hydrazine & $\begin{array}{l}\text { Derivatization using benzaldehyde, followed by LLE. } \\
\text { HPLC with a } 5 \mu \mathrm{m} \text { cyanosilyl stationary phase (R type) } \\
\text { at } 30{ }^{\circ} \mathrm{C} \text {. Mobile phase: 2-propanol/hexane }(5 / 95, \mathrm{v} / \mathrm{v}) . \\
\text { Flow rate } 1.5 \mathrm{ml} / \mathrm{min} \text {; detection at } 310 \mathrm{~nm} .\end{array}$ \\
\hline $\begin{array}{l}\text { API (general } \\
\text { method) }\end{array}$ & Hydrazine & $\begin{array}{l}\text { HPLC with }(1) 5 \mu \mathrm{m} \text { ZIC HILIC (SeQuant), (2) } 5 \mu \mathrm{m} \\
\text { Develosil } 100 \text { Diol-5(Nomura), }(3) 5 \mu \mathrm{m} \text { TSK-Gel } \\
\text { Amide- } 80 \text { (Tosoh Bioscience) and }(4) 5 \mu \mathrm{m} \text { Zorbax } \mathrm{NH}_{2} \\
\text { (Agilent) at different column temperatures }\left(10-60^{\circ} \mathrm{C}\right) . \\
\text { Mobile phase: TFA/water/ethanol }(0.1 / 30 / 70, \mathrm{v} / \mathrm{v}) . \\
\text { Flow rate } 0.4 \mathrm{ml} / \mathrm{min} \text {; CLND detection. }\end{array}$ \\
\hline
\end{tabular}




\begin{tabular}{|c|c|c|}
\hline $\begin{array}{l}\text { Active Potential } \\
\text { Ingredient (API) }\end{array}$ & Impurities & Method details \\
\hline $\begin{array}{l}\text { API (general } \\
\text { method) }\end{array}$ & Hydrazine & $\begin{array}{l}\text { (1) Derivatization using benzaldehyde. HPLC } \\
\text { with no operating conditions reported. (2) LSE, } \\
\text { followed by derivatization using benzaldehyde } \\
\text { at lower temperatures. HPLC with no } \\
\text { operating conditions reported. Detection at } \\
190 \mathrm{~nm} \text {. }\end{array}$ \\
\hline Azelastine & $\begin{array}{l}\text { Impurity A: } \\
\text { benzohydrazide, } \\
\text { impurity B: 1- } \\
\text { benzoyl-2-[(4RS)-1- } \\
\text { methylhexahydro- } \\
\text { 1Hazepin-4yl] } \\
\text { diazane }\end{array}$ & $\begin{array}{l}\text { HPLC with a } 10 \mu \mathrm{m} \text { cyanosilyl stationary phase }(\mathrm{R}) \text { at } \\
30^{\circ} \mathrm{C} \text {. Mobile phase: } \mathrm{pH} 3.0 \text { phosphate buffer and } \\
\text { sodium octane sulphonic acid in water/acetonitrile } \\
(740 / 260, \mathrm{v} / \mathrm{v}) \text {. Flow rate } 2.0 \mathrm{ml} / \mathrm{min} \text {; detection at } 210 \\
\mathrm{~nm} .\end{array}$ \\
\hline Aryl hydrazones & E-Aryl hydrazones & $\begin{array}{l}\text { HPLC with a } 5 \mu \mathrm{m} \text { ODS stationary phase (Merck } \\
\text { LiChrospher) at } 25^{\circ} \mathrm{C} \text {. Mobile phase: } 1 \mathrm{mM} \text { pH } 6.0 \\
\text { phosphate buffer with } 2 \mathrm{mM} \text { EDTA and methanol } \\
(40 / 60, \mathrm{v} / \mathrm{v}) \text {. Flow rate } 1.0 \mathrm{ml} / \mathrm{min} \text {; detection at } 200-400 \\
\text { nm (DAD). } \\
\text { HPLC with a } 5 \mu \mathrm{m} \text { phenyl hexyl stationary phase } \\
\text { (Phenomenex Luna) at } 25^{\circ} \mathrm{C} \text {. Mobile phase: water and } \\
\text { acetonitrile ( } 50 / 50, \mathrm{v} / \mathrm{v}) \text {. Flow rate } 0.3 \mathrm{ml} / \mathrm{min} \text {. Positive } \\
\text { and negative ion mode ESI with ion trap analyzer in } \\
\text { SIM mode (M }+\mathrm{H} \text { ion). Range } 50-1000 \mathrm{~m} / \mathrm{z} \text {. Voltage } 4 \\
\mathrm{kV} \text {, capillary temperature } 250^{\circ} \mathrm{C} \text {. }\end{array}$ \\
\hline Carbidopa & Hydrazine & $\begin{array}{l}\text { Derivatization using benzaldehyde, followed by LLE. } \\
\text { HPLC with a } 5 \mu \mathrm{m} \text { ODS stationary phase (Altima C18 or } \\
\text { Hypersil ODS). Mobile phase: aqueous } 0.03 \% \text { EDTA } \\
\text { and acetonitrile ( } 300 / 700, \mathrm{v} / \mathrm{v}) \text {. Flow rate } 1.0 \mathrm{ml} / \mathrm{min} \text {; } \\
\text { detection at } 305 \mathrm{~nm} .\end{array}$ \\
\hline Celecoxib & $\begin{array}{l}\text { Intermediate I: } 4- \\
\text { hydrazine benzene } \\
\text { sulphonamide }\end{array}$ & $\begin{array}{l}\text { HPLC with a } 4 \mu \mathrm{m} \text { ODS stationary phase (NovapaK } \\
\text { C18). Mobile phase: } \mathrm{pH} 4.810 \mathrm{mM} \text { phosphate buffer and } \\
\text { acetonitrile }(450 / 550, \mathrm{v} / \mathrm{v}) \text {. Flow rate } 1.0 \mathrm{ml} / \mathrm{min} \text {; } \\
\text { detection at } 252 \mathrm{~nm} \text {. }\end{array}$ \\
\hline Copovidone & Hydrazine & $\begin{array}{l}\text { Derivatization using benzaldehyde, followed by LLE. } \\
\text { HPLC with a } 5 \mu \mathrm{m} \text { ODS stationary phase (Altima C18 or } \\
\text { Hypersil ODS). Mobile phase: aqueous } 0.03 \% \text { EDTA } \\
\text { and acetonitrile }(300 / 700, \mathrm{v} / \mathrm{v}) \text {. Flow rate } 1.0 \mathrm{ml} / \mathrm{min} \text {; } \\
\text { detection at } 305 \mathrm{~nm} .\end{array}$ \\
\hline $\begin{array}{l}\text { Dihydralazine } \\
\text { sulphate }\end{array}$ & $\begin{array}{l}\text { Hydrazine } \\
\text { (impurity B) }\end{array}$ & $\begin{array}{l}\text { Derivatization using benzaldehyde, followed by LLE. } \\
\text { HPLC with a } 5 \mu \mathrm{m} \text { ODS stationary phase (R type). } \\
\text { Mobile phase: aqueous } 0.03 \% \text { EDTA and acetonitrile } \\
(300 / 700, \mathrm{v} / \mathrm{v}) \text {. Flow rate } 1.0 \mathrm{ml} / \mathrm{min} \text {; detection at } 305 \\
\mathrm{~nm} .\end{array}$ \\
\hline
\end{tabular}




\begin{tabular}{|c|c|c|}
\hline $\begin{array}{l}\text { Active Potential } \\
\text { Ingredient (API) }\end{array}$ & Impurities & Method details \\
\hline Ebifuramin & $\begin{array}{l}\text { Impurity III: }(+)-5- \\
\text { morpholino methyl- } \\
\text { 3-(5- } \\
\text { nitrofurfurylidene } \\
\text { amino)-oxazolidin- } \\
\text { 2-one }\end{array}$ & $\begin{array}{l}\text { HPLC with a } 5 \mu \mathrm{m} \text { ODS stationary phase (Hypersil } \\
\text { ODS). Mobile phase: acetonitrile/THF/pH } 2.610 \mathrm{mM} \\
\text { dibutyl aminephosphate }(15 / 5 / 80, \mathrm{v} / \mathrm{v} / \mathrm{v}) . \text { Flow rate } \\
1.5 \mathrm{ml} / \mathrm{min} \text {; detection at } 254 \mathrm{~nm} .\end{array}$ \\
\hline Hydralazine & Hydrazine & $\begin{array}{l}\text { Derivatization using benzaldehyde, followed by LLE. } \\
\text { HPLC with a } 5 \mu \mathrm{m} \text { ODS stationary phase (Altima C18 or } \\
\text { Hypersil ODS). Mobile phase aqueous } 0.03 \% \text { EDTA and } \\
\text { acetonitrile }(300 / 700, \mathrm{v} / \mathrm{v}) \text {. Flow rate } 1.0 \mathrm{ml} / \mathrm{min} \text {; } \\
\text { detection at } 305 \mathrm{~mm} \text {. }\end{array}$ \\
\hline $\begin{array}{l}\text { Hydralazine } \\
\text { tablets }\end{array}$ & $\begin{array}{l}\text { Hydralazine } \\
\text { hydrazone }\end{array}$ & $\begin{array}{l}\text { HPLC with a } 10 \mu \mathrm{m} \text { ODS stationary phase (Waters } \\
\mu \text { Bondapak) at room temperature. Mobile phase: } \\
\text { acetonitrile } / 5 \mathrm{mM} \text { SDS/ phosphoric acid }(150 / 850 / 0.45 \text {, } \\
\mathrm{v} / \mathrm{v} / \mathrm{v}) . \text { Flow rate } 2.0 \mathrm{ml} / \mathrm{min} \text {; detection at } 220 \mathrm{~nm} \text {. }\end{array}$ \\
\hline Isoniazid & $\begin{array}{l}\text { Impurity I: 1- } \\
\text { nicotinyl-2- lactosyl } \\
\text { hydrazine }\end{array}$ & $\begin{array}{l}\text { HPLC with a } 10 \mu \mathrm{m} \text { cyanopropyl stationary phase and a } \\
\text { mobile phase consisting of a mixture of } \mathrm{pH} 3.510 \mathrm{mM} \\
\text { acetate buffer and acetonitrile }(95 / 5, \mathrm{v} / \mathrm{v}) \text {. Flow rate } \\
\text { and detection wavelength not specified. }\end{array}$ \\
\hline Isoniazid & $\begin{array}{l}\text { Hydrazine (I), } \\
\text { isonictonic acid-N'- } \\
\text { (pyridyl-4- } \\
\text { carbonyl) } \\
\text { hydrazide (II), } \\
\text { isonictonic acid- } \\
\text { pyridine-4- } \\
\text { ylmethylene } \\
\text { hydrazide (III), } \\
\text { isonictonic acid } \\
\text { ethylidene } \\
\text { hydrazide) (IV) }\end{array}$ & $\begin{array}{l}\text { HPLC with a } 5 \mu \mathrm{m} \text { ODS stationary phase (Zorbax XDB } \\
\text { Eclipse C18). Mobile phase water and acetonitrile } \\
(960 / 40, \mathrm{v} / \mathrm{v}) . \text { Flow rate } 0.5 \mathrm{ml} / \mathrm{min} \text {; detection at } 252 \\
\mathrm{~nm} .\end{array}$ \\
\hline Isoniazid & Hydrazine & $\begin{array}{l}\text { HPLC-MS using negative electrospray ionization ESI } \\
\text { with a Bruker Daltonics ToF. TLC with a silica gel } F_{254} \\
\text { TLC plate with a water/acetone/methanol/ethylacetate } \\
(10 / 20 / 20 / 50, v / v) \text { mobile phase. Visualization using } \\
\text { dimethyl aminobenzaldehyde solution; examination } \\
\text { under daylight. }\end{array}$ \\
\hline Mildronate & $\begin{array}{l}\text { Impurity 2: 1,1,1- } \\
\text { trimethyl } \\
\text { hydrazinium } \\
\text { bromide }\end{array}$ & $\begin{array}{l}\text { HILIC with a } 3 \mu \mathrm{m} \text { silica stationary phase (Atlantis } \\
\text { HILIC silica, Alltima HP silica, and Spherisorb silica), } 5 \\
\mu \mathrm{m} \text { cyano stationary phase (Discovery cyano), } 3 \mu \mathrm{m} \\
\text { amino stationary phase (Hypersil APS- } 1 \text { ), and } 5 \mu \mathrm{m} \\
\text { sulfobetaine stationary phase (ZIC-HILIC) at } 30^{\circ} \mathrm{C} \text {. } \\
\text { Mobile phase acetonitrile and } 0.1 \% \text { formic acid in water. } \\
\text { Flow rate } 0.2 \mathrm{ml} / \mathrm{min} \text { with positive ion mode ESI } \\
\text { detection at } 20-35 \mathrm{kV} \text { using a triple quadra pole MS. }\end{array}$ \\
\hline
\end{tabular}




\begin{tabular}{|c|c|c|}
\hline $\begin{array}{l}\text { Active Potential } \\
\text { Ingredient (API) }\end{array}$ & Impurities & Method details \\
\hline $\begin{array}{l}\text { Nitrofural, } \\
\text { nitrofurazone and } \\
\text { nitrofuroxazide }\end{array}$ & Hydrazine & $\begin{array}{l}\text { Derivatization using benzaldehyde, followed by LLE. } \\
\text { HPLC with a } 5 \mu \mathrm{m} \text { ODS stationary phase (Altima C18 or } \\
\text { Hypersil ODS). Mobile phase aqueous } 0.03 \% \text { EDTA and } \\
\text { acetonitrile }(300 / 700, \mathrm{v} / \mathrm{v}) \text {. Flow rate } 1.0 \mathrm{ml} / \mathrm{min} \text {; } \\
\text { detection at } 305 \mathrm{~nm} .\end{array}$ \\
\hline Nitrofurazone & $\begin{array}{l}\text { Impurity A: Bis- } \\
{[(5-\text {-nitrofuran-2- yl })} \\
\text { methylene] diazane }\end{array}$ & $\begin{array}{l}\text { HPLC with a } 5 \mu \mathrm{m} \text { ODS stationary phase (R type). } \\
\text { Mobile phase acetonitrile/water }(400 / 600, \mathrm{v} / \mathrm{v}) \text {. Flow } \\
\text { rate } 1.0 \mathrm{ml} / \mathrm{min} \text {; detection at } 310 \mathrm{~nm} \text {. }\end{array}$ \\
\hline Povidone & Hydrazine & $\begin{array}{l}\text { Derivatization using benzaldehyde, followed by LLE. } \\
\text { HPLC with a } 5 \mu \mathrm{m} \text { ODS stationary phase (Altima C18, } \\
\text { Hypersil ODS). Mobile phase aqueous } 0.03 \% \text { EDTA and } \\
\text { acetonitrile }(300 / 700, \mathrm{v} / \mathrm{v}) \text {. Flow rate } 1.0 \mathrm{ml} / \mathrm{min} \text {; } \\
\text { detection at } 305 \mathrm{~nm} .\end{array}$ \\
\hline $\begin{array}{l}\text { Pyridoxal } \\
\text { isonicotinoyl } \\
\text { hydrazone }\end{array}$ & $\begin{array}{l}\text { Hydrazine, } \\
\text { isoniazid }\end{array}$ & $\begin{array}{l}\text { HPLC with } 5 \mu \mathrm{m} \text { ODS (Nucleosil C18) and an isocratic } \\
\text { mobile phase consisting of a mixture of methanol (A) } \\
\text { and pH } 3.010 \mathrm{mM} \text { phosphate buffer containing } 5 \mathrm{mM} 1- \\
\text { heptane sulphonic acid and } 2 \mathrm{mM} \text { EDTA (B) in a ratio of } \\
49 / 51, \mathrm{v} / \mathrm{v} \text {. Flow rate } 0.9 \mathrm{ml} / \mathrm{min} \text {; detection at } 297 \text { and } \\
254 \mathrm{~nm} \text {. }\end{array}$ \\
\hline Rifampicin & $\begin{array}{l}\text { Hydrazones: } \\
\text { rifampicin quinone } \\
\text { and 25-desacetyl } \\
\text { rifampicin }\end{array}$ & $\begin{array}{l}\text { HPTLC with a silica gel } 60 \text { TLC plate (Merck) with a } \\
\text { chloroform/methanol/water }(80 / 20 / 2.5, \mathrm{v} / \mathrm{v} / \mathrm{v}) \text { mobile } \\
\text { phase. Examined using Scanner II (Camag) at 330nm for } \\
\text { 25-desacetyl rifampicin and } 490 \mathrm{~nm} \text { for rifampicin } \\
\text { quinone. }\end{array}$ \\
\hline Rifampicin & $\begin{array}{l}\text { Hydrazones: } \\
\text { rifampicin quinone }\end{array}$ & $\begin{array}{l}\text { HPLC with } 10 \mu \mathrm{m} \text { silyl and } 10 \mu \mathrm{m} \text { nitrile stationary } \\
\text { phases (Micro Pak Si-10 and MicroPak CN, respectively) } \\
\text { and anisocratic mobile phase consisting of a mixture of } \\
\text { chloroform and methanol of varying proportions. Flow } \\
\text { rate } 0.2-0.7 \mathrm{ml} / \mathrm{min} \text {; detection at } 334 \mathrm{~nm} \text {. }\end{array}$ \\
\hline Rifampicin & $\begin{array}{l}\text { Hydrazones: } \\
\text { rifampicin quinone, } \\
\text { 25-desacetyl-21- } \\
\text { acetyl-rifampicin, } \\
\text { 25-desacetyl-23- } \\
\text { acetyl-rifampicin }\end{array}$ & $\begin{array}{l}\text { HPLC with direct injection (DI) onto a } 3 \mu \mathrm{m} \text { ODS } \\
\text { stationary phase (Hypersil ODS) at } 25^{\circ} \mathrm{C} \text { and an } \\
\text { isocratic mobile phase consisting of a mixture of } \mathrm{pH} 7.4 \\
50 \mathrm{mM} \text { phosphate buffer and acetonitrile }(64 / 36, \mathrm{v} / \mathrm{v}) \\
\text { Flow rate } 1.4 \mathrm{ml} / \mathrm{min} \text {; detection at } 240 \mathrm{~nm} \text {. } \\
\text { Alternatively, a } 10 \mu \mathrm{m} \text { ODS stationary phase (Hypersil } \\
\text { ODS) }\end{array}$ \\
\hline $\begin{array}{l}\text { Rifampicin, } \\
\text { isoniazid, } \\
\text { pyrazinamide } \\
\text { FDC }\end{array}$ & $\begin{array}{l}\text { Hydrazones: } \\
\text { rifampicin quinone, } \\
\text { desacetyl } \\
\text { rifampicin, } \\
\text { isonicotinyl } \\
\text { hydrazone }\end{array}$ & $\begin{array}{l}\text { HPLC with a } 5 \mu \mathrm{m} \text { L1 ODS stationary phase at } 25^{\circ} \mathrm{C} \\
\text { and a gradient mobile phase consisting of varying } \\
\text { mixtures of mobile phase A (pH } 6.8 \text { phosphate } \\
\text { buffer/acetonitrile, } 96 / 4, \mathrm{v} / \mathrm{v}) \text { and mobile phase } \mathrm{B}(\mathrm{pH} \\
6.8 \text { phosphate buffer/acetonitrile, } 45 / 55, \mathrm{v} / \mathrm{v} \text { or } 55 / 45, \\
\text { v/v). Flow rate } 1.5 \text { or } 1.0 \mathrm{ml} / \mathrm{min} \text {; detection at } 238 \mathrm{~nm} \text {. } \\
\text { Three L1 columns were evaluated: } 1 \text { : Zorbax XDB, } 2 \text { : } \\
\text { Shim-pak CLC ODS and 3. Nucleosil EC } 120-5 \text {. }\end{array}$ \\
\hline
\end{tabular}




\begin{tabular}{|l|l|l|}
\hline $\begin{array}{l}\text { Active Potential } \\
\text { Ingredient (API) }\end{array}$ & Impurities & Method details \\
\hline Rizatriptan & $\begin{array}{l}\text { Impurity I: 1-(4- } \\
\text { hydrazinophenyl) } \\
\text { methyl-1,2,3- } \\
\text { triazole }\end{array}$ & $\begin{array}{l}\text { HPLC with a } 5 \mu \mathrm{m} \text { nitrile stationary phase (Zorbax SB- } \\
\mathrm{CN}) \text { at } 25^{\circ} \mathrm{C} \text { and a gradient mobile phase consisting of } \\
\text { varying mixtures of pH } 3.410 \mathrm{mM} \text { phosphate buffer, } \\
\text { acetonitrile, and methanol. Flow rate } 1.0 \mathrm{ml} / \mathrm{min} ; \\
\text { detection at } 225 \mathrm{~nm} .\end{array}$ \\
\hline $\begin{array}{l}\text { Vindesine } \\
\text { sulphate }\end{array}$ & $\begin{array}{l}\text { Impurity C } \\
\text { (desacetyl } \\
\text { vinblastine } \\
\text { hydrazide) }\end{array}$ & $\begin{array}{l}\text { HPLC with a } 5 \mu \mathrm{m} \text { ODS stationary phase (R type) and a } \\
\text { gradient mobile phase consisting of varying mixtures of } \\
\text { pH } 7.5 \text { diethyl aminephosphate buffer and methanol. } \\
\text { Flow rate } 2.0 \mathrm{ml} / \text { min; detection at } 270 \mathrm{~nm} .\end{array}$ \\
\hline
\end{tabular}

Table 4. Various HPLC methods used for a wide range of drugs; Abbreviations: DAD: diode array detection; EC: electrochemical detection; ESI: electrospray ionization; FDC: Fixed Dose Combination; HILIC: hydrophobic interaction liquid chromatography; LLE: liquid liquid extraction; LSE: liquid solid extraction; MS: mass spectroscopy; ODS: octadecyl silyl; SDS: sodium dodecyl sulphate; SIM: single ion monitoring; ToF: time of flight (Elder et al., 2010c).

The use of water as sample diluent could pose a limitation for this separation technique, especially when high water content is required for dissolving the drug substance or the formulated drug product (Liu et al., 2010).

\subsection{GC methods}

GC methods are commonly used for the analysis of several volatile small molecule GIs. Some examples include the liquid injection technique and the headspace sampling technique. Liquid injection is prone to contamination in which injection of a large amount of non-volatile API can accumulate in the injector liner or on the head of the GC column, which can cause a sudden deterioration in method performance. Headspace injection, on the other hand, is desirable because it minimizes potential contamination of the injector or column by avoiding the introduction of a large quantity of API (Liu et al., 2010).

David et al. (2010) proposed a method selection chart (Figure 4) containing GC or LC methods, both in combination with a single quadrupole mass spectrometer as detector. These methods applied for a wide range of analytes including sulphonates, alkyl halides, and epoxides.

Nassar et al. (2009) developed a GC/MS method for residual levels of EMS in a mesylate salt of an API crystallized from ethanol. The method was capable of detecting EMS down to levels of 50-200 ppb. Subsequently, extraction techniques were developed for eliminating or reducing matrix related interference. Thus, Colon and Richoll (2005) surveyed liquid-liquid extraction (LLE), liquid phase micro-extraction (LPME), solid phase extraction (SPE), and solid phase micro-extraction (SPME) coupled with GC/MS and single ion-monitoring (SIM). Using these approaches, they developed limit tests $(5 \mathrm{ppm})$ for some alkyl aryl esters of sulfonic acids.

Similar attempts were made for reducing or eliminating the matrix effect for alkylating agents as well. In all these procedures, a specific physical property of the analyte not shared by the matrix was utilized, e.g. low boiling point and/or in the presence of halide atom (Elder et al., 2008a). 
GC methods were rarely used for the analysis of epoxides/hydroperoxides, as compared to other impurities, owing to the size of molecule and the volatility properties within this group (Elder et al., 2010b). Klick (1995) used a GC method for the determination of residual levels of a chlorohydrin and the corresponding epoxide impurities in almokalant. Other literatures give an account of GC-MS methods for the analysis of volatile components in traditional Chinese herbal medicines (Yu et al., 2007; Guo et al., 2003).

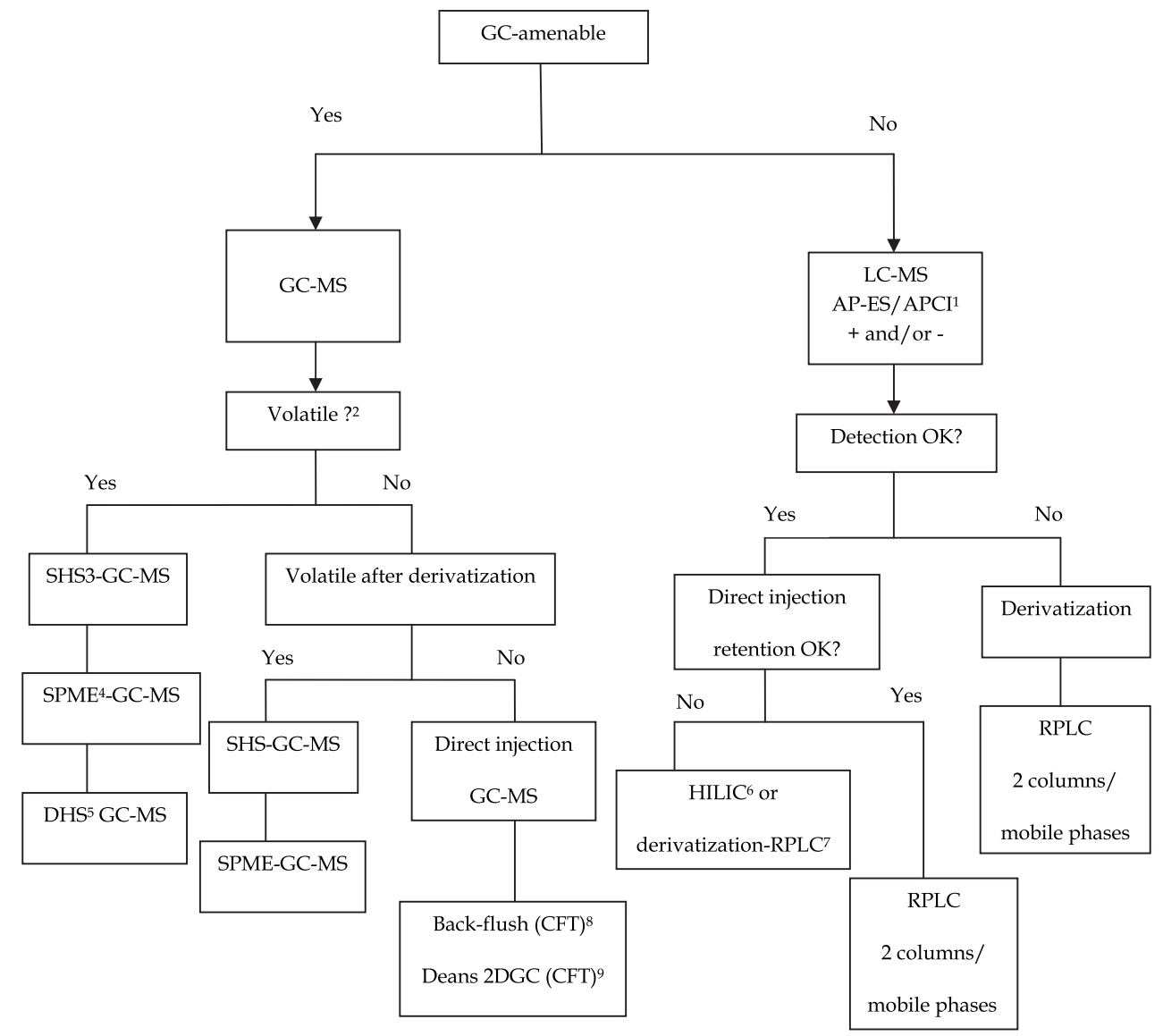

Fig. 4. Method selection chart for analyzing genotoxic impurities with GC/LC; ${ }^{1} \mathrm{AP}-$

ES/APCI: atmospheric pressure electrospray ionization/ atmospheric pressure chemical ionization; ${ }^{2}$ If the analyte has sufficient vapor pressure in water or other low volatile solvent; ${ }^{3}$ SHS: static headspace; ${ }^{4}$ SPME: solid-phase micro-extraction; ${ }^{5}$ DHS: dynamic headspace; ${ }^{6}$ HILIC: hydrophobic interaction liquid chromatography; ${ }^{7}$ derivatization-RPLC: reversed phase HPLC with precolumn derivatization; 8 Back-flush (CFT): capillary flow technology based back-flushing; 9 Deans 2DGC (CFT): capillary flow technology based twodimensional GC (Figure is reproduced from David et al., 2010).

For the hydrazine group the normal flame ionization detection (FID) in GC analysis is not appropriate because these compounds possess no carbon atoms (Elder et al., 2010c). A GC 
procedure involving the formation of a benzalazine derivative was developed for monitoring the residual levels of hydrazine in hydralazine and isoniazid APIs, tablets, combined tablets, syrups, and injectable products in which nitrogen selective detection was used (Matsui et al., 1983).

In addition, Carlin et al. (1998) adapted a previously published method for monitoring a benzalazine derivative using GC with electron capture (EC) detection. The LOQ was $10 \mathrm{ppm}$ and the method was linear over the range of 10-100 ppm. The inter-day residual standard deviation (RSD) based on six measurements at analyte levels of 10 ppm was $15 \%$; however, this improved slightly at increased analyte concentrations of 25 and $100 \mathrm{ppm}$, to $9.5 \%$ and $11.3 \%$, respectively.

Nevertheless, non-volatile API does not partition into the headspace and therefore does not enter the GC system; as a result, headspace injection becomes the preferred choice whenever possible (Liu et al., 2010).

\subsection{TLC/HPTLC methods}

In general practice, thin layer chromatography (TLC) is not preferred for the accurate determination of very low residual analyte level. However, this technique is still used for the determination of related substances in the pharmacopoeial monographs for amiodarone, bromazepam, carmustine, ifosamide, indoramin, and tolnaftate (Elder et al., 2008).

Nevertheless, there are several examples of its use in association with determining levels of the epoxyl alkaloid, including scopolamine in extracts of Datura stramonium. Sass and Stutz (1981) used TLC to determine residual sulfur and nitrogen mustards (beta haloethyl compounds) in a variety of substrates in which the sensitivities in the microgram range were typically achievable. High performance thin layer chromatography (HPTLC) was used for monitoring the degradation products of rifampicin, including the hydrazones (25-desacetyl rifampicin (DAR)) and rifampicin quinone (RQU). Finally, it was concluded that the method is suitable for routine quality control and stability analyses, especially in the developing world (Jindal et al. 1994).

\subsection{Capillary electrophoresis methods}

Jouyban and Kenndler (2008) reviewed the applicability of capillary electrophoresis (CE) methods for the analysis of pharmaceutical impurities. In addition, they discussed the applications of these methods in various groups of compounds such as chemotherapeutic agents, central nervous system (CNS) drugs, histamine receptor and cardiovascular drugs.

The main advantage of CE techniques is their selectivity; thus, they are suitable for the analysis of complex herbal products. Bempong et al. (1993) reported the separation of 13-cis and all-trans retinoic acid and their photo-degradation products (including all-trans-5, 6epoxy retinoic acid, 13-cis-5, 6-epoxy retinoic acid) using both capillary zone electrophoresis (CZE) and micellar electrokinetic chromatography (MEKC) methods. A Chinese research group reported the development of $\mathrm{CE}$ methods for the simultaneous determination of some hydrazine related impurities (Liu et al., 1996).

Hansen and Sheribah (2005) evaluated a series of electrically driven separation techniques: CZE, MEKC, and microemulsion electrokinetic chromatography (MEEKC) for the determination of residual alkylating impurities in bromazepam API. However, the poor sensitivity of the techniques posed a problem even when specialized detection cells (e.g. bubble or Z-cells) were used. Mahuzier et al. (2001) demonstrated the poor sensitivity of CE 
based methods, in comparison to other separation methods. The problem of limited sensitivity of CE methods can be solved either by the use of detection methods with sensitivity higher than UV absorption or by pre-concentration of the analytes (Jouyban and Kenndler, 2008).

\subsection{Enhancing methods}

Alternatively, the structure of the molecule as well as its properties can be altered to enhance detectability which in turn will help to achieve the desired sensitivity. This is especially true for GIs that lack structural features for sensitive detection (Bai et al., 2010; Liu et al., 2010). A number of general approaches could be considered, some of which are explained below:

\subsubsection{Chemical derivatization}

This method is generally used for stabilizing reactive GIs and for introducing a detection specific moiety for enhanced detection, i.e. chromophore for UV. Also, this method sometimes produces a single compound for several GIs; thus, it becomes non-specific which can be considered as an advantage in determining a group of structurally related compounds (Liu et al., 2010). Bai et al. (2010) introduced a chemical derivatization method for analyzing two alkyl halides and one epoxide. The objective of the three derivatization reactions is to generate a strong basic center by introducing an amine functional group. All three derivatization products are good candidates for electrospray ionization (ESI)-MS owing to the high proton affinity or the permanent charge.

\subsubsection{Coordination ion spray-MS}

Owing to their structural features, several analytes are not amenable to atmospheric pressure ionization methods, such as the ESI method. Alkali metal ions such as $\mathrm{Li}^{+}, \mathrm{Na}^{+}$, and $\mathrm{K}^{+}$can form complexes with some organic molecules in the gas phase; this fact could be used as a solution for the analytes subjected previously (Liu et al., 2010).

\subsubsection{Matrix deactivation}

The matrix deactivation approach is a chemical approach to stabilize unstable/reactive analytes. It is based upon the hypothesis that the instability of certain GIs at trace level is caused by the reaction between the analytes and reactive species in the sample matrix. Thus, controlling the reactivity of the reactive species in the sample matrix would stabilize the unstable/reactive GI analytes (Liu et al., 2010).

As an example the alkylators are reactive unknown impurities which possess mainly nucleophilic characteristics. Their reactivity can be attenuated by either protonation or scavenging approaches. Sun et al. (2010) reported a matrix deactivation methodology for improving the stability of unstable and reactive GIs for their trace analysis. This approach appears to be commonly applicable to techniques like direct GC-MS and LC-MS analyses, or coupled with chemical derivatization as well.

\section{Genotoxicity prediction}

The concept of using structural alerts to predict potential genotoxic activity for identified impurities is now well established; however, the concordance between such alerts and biologically relevant genotoxic potential (in the context of genotoxic impurities) could be 
highly imperfect. Structural alerts are defined as molecular functionalities (structural features) that are known to cause toxicity, and their presence in a molecular structure alerts the investigator to the potential toxicities of the test chemical. Nevertheless, the assumption that any impurity with a structural alert is potentially DNA-reactive and thus subject to the default TTC limit may often lead to unnecessary restrictive limits. From a resource and time table viewpoint of a new drug production, the experimental determination of genotoxicity is not feasible for millions of drug candidates in the pharmaceutical industry. Thus, compounds identified as potential hazards by in silico methods would be high priority candidates for confirmatory laboratory testing (Kruhlak et al., 2007; Snodin, 2010).

In silico toxicology is the application of computer technologies to analyze existing data, model, and predict the toxicological activity of a substance. In sequence, toxicologically based QSARs are mathematical equations used as a predictive technique to estimate the toxicity of new chemicals based upon a model of a training set of chemicals with known activity and a defined chemical space (Valerio, 2009).

Ashby and Tennant (1991) reported some correlations of electrophilicity with DNA reactivity (assessed by Ames-testing data) for about 300 chemicals and elucidated the concept of structural alerts for genotoxic activity in the 1980s/1990s. Using a database of $>4000$ compounds, Sawatari et al. (2001) determined correlations between 44 substructures and bacterial mutagenicity data. A high proportion of genotoxic compounds were found for electrophilic reagents such as epoxides $(63 \%)$, aromatic nitro compounds $(49 \%)$, and primary alkyl monohalides (46\%). In a retrospective analysis of starting materials and intermediates involved in API syntheses, the most common structurally alerting groups were found to be aromatic amines, aromatic nitros, alkylating agents and Michael acceptors (Snodin, 2010).

One of the strengths of QSAR models is that they contribute to a mechanistic understanding of the activity, and, at the same time, they constitute practical tools to predict the activity of further, untested chemicals solely based on chemical structure (Benigni et al., 2005). Another strength of QSAR models is that they are strictly data-driven, and are not based on a prior hypotheses. On the other hand, high-quality experimental data must be used to build the training data set. As error (e.g. incorrect molecular structure or erroneous data from toxicology studies of a chemical) is introduced into the model, amplification of that error is generated and represented in the prediction (Benigni et al., 2005; Valerio, 2009).

Cunningham et al. (1998) investigated a SAR analysis of the mouse subset of the carcinogenic potency database (CPDB) which also included chemicals tested by the US national toxicology program (NTP). This database consisted of 627 chemicals tested in mice for carcinogenic activity with the tumorigenicity data being standardized and reported as $\mathrm{TD}_{50}$ values. In addition, MULTICASE software (www.multicase.com) was used to identify several structural features that are not explained by an electrophilic mechanism and which may be indicative of non-genotoxic chemicals or mechanisms involved in carcinogenesis other than mutations. The prediction capabilities of the system for identifying carcinogens and noncarcinogens were $70 \%$ and $78 \%$ for a modified validation set.

Tafazoli et al. (1998) used the micronucleus (MN) test and the alkaline single cell gel electrophoresis (Comet) assay for analyzing potential mutagenicity, genotoxicty, and cytotoxicity of five chlorinated hydrocarbons. Using the generated data as well as the data of another five related chemicals that were investigated previously, a QSAR analysis was performed and the results indicated that $\mathrm{LB}_{\mathrm{C}_{-} \mathrm{C} 1}$ (longest carbon-chlorine bond length), $\mathrm{MR}$ 
(molar refractivity), and $\mathrm{E}_{\mathrm{Lum} 0}$ (energy of the lowest unoccupied molecular orbital, indicating electrophilicity) were the most significant factors to be considered for discriminating between genotoxins and nongenotoxins.

Benigni et al. (2005) showed that the QSAR models could correctly predict-- based only on the knowledge of the chemical structure--the genotoxicity of simple and unsaturated aldehydes. The active and inactive compounds were separated based on the hydrophobicity $(\log \mathrm{P})$ and bulkiness $(\mathrm{MR})$ properties.

Bercu et al. (2010) used in silico tools to predict the cancer potency $\left(\mathrm{TD}_{50}\right)$ of a compound based on its structure. SAR models (classification/regression) were developed from the carcinogenicity potency database using MULTICASE and VISDOM (a Lilly Inc. in-house software).

It is commonly accepted that the carcinogenicity of chemicals is owing to their genotoxicity and, in fact, the mutation and carcinogenesis data are practically coincident. Thus, the two endpoints were collapsed into one "genotoxicity" classification, in which QSAR analysis was applied. Now the question remains as to how to predict non-genotoxic carcinogenicity. In fact, it cannot be well approached until some mechanistic understanding of nongenotoxic carcinogenesis is achieved. At this time, this approach is unable to grasp the structural features of non-genotoxic carcinogens (Ashby, 1990; Cunningham et al., 1998; Benigni et al., 2005).

The other limitation to currently available QSARs is the lack of models for organometallics, complex mixtures (e.g. herbal extracts), and high molecular weight compounds such as polymers (Valerio, 2009). However, the QSAR predictive software offers a rapid, reliable, and cost effective method of identifying the potential risk of chemicals that are well represented in QSAR training data sets, even when experimental data are limited or lacking (Kruhlak et al., 2007). These models should be further developed/validated by employing new mechanistic findings and using newly reported experimental data.

\section{Conclusion}

Since 2007, following the EMEA suspension of the marketing authorization of viracept (nelfinavir mesylate), genotoxic impurities have become a common issue for health concerns. Thus, regulatory agencies have made several attempts to construct a systematic method for controlling and analyzing GIs. However, several points must be considered for achieving a general view on the regulation of GIs.

One of the main problems is the very conservative limit regulated by agencies $(1.5 \mu \mathrm{g} /$ day). Bercu et al. (2009) calculated the permissible daily exposure (PDE) for EMS, which was the first GI of concern in 2007, as $0.104 \mathrm{mg} /$ day. This value was found to be about 70 -fold higher than the TTC level of $1.5 \mu \mathrm{g} /$ day currently applied to EMS based on the generic linear back extrapolation model for genotoxins acting via non-threshold mechanisms. Other literatures highlighted this conservative limit as well (Gocke et al., 2009b; Elder et al., 2010a; Snodin, 2010). In addition, Gocke et al. (2009b) reported that the accidental exposure of viracept patients did not result in an increased likelihood for adverse genotoxic, teratogenic or cancerogenic effects.

In addition to the challenge of setting a more pragmatic limit for GIs, the development of extremely sensitive and robust analytical methods that can adequately monitor GIs at very low levels is very difficult. Also, the pharmaceutical industry has no long-term experience in the use of these methodologies within the factory setting. Thus, analysts make attempts to 
determine a way for analyzing various GIs by using unique robust methods as far as possible. In this way, simple HPLC/UV or GC/FID methods are usually performed at the first stage, while more complicated LC/MS or LC/MS/MS methods are used as alternatives (Dobo et al., 2006; Elder et al., 2008b; Liu et al., 2010).

Teasdale et al. (2009) studied the formation of sulfonate esters as a mechanistic view, and showed that when a slight excess of base is present, there is no discernible reaction rate to form the sulfonate ester and no mechanistic pathway to their formation. From this point of view, the formation of GIs and suspicious substances in the API syntheses can be easily avoided, and therefore this is the preferred option (Robinson, 2010).

Finally, it can be mentioned that in such a situation, in silico approaches can prove to be a more effective solution in terms of time and cost for screening genotoxic compounds. As subjected by Luis and Valerio (2009), high-quality experimental data must be used. In addition, for non-genotoxic carcinogens, QSAR studies can provide a better understanding about the mechanism of carcinogenesis of these compounds. The in silico methods used in agencies have not been specified yet; however, by overcoming the limits these can become an innate part of regulatory systems.

\section{Acknowledgment}

This work is dedicated to Professor Hassan Mohseni, Tabriz University of Medical Sciences, Tabriz, Iran, for his enduring efforts in training toxicology in Iran.

\section{References}

Agency for Toxic Substance and Disease Registry. (1997). Toxicological profile for hydrazines, In: Agency for Toxic Substances and Disease Registery, 11 Feb, 2011, Available from: <http://www.atsdr.cdc.gov/toxprofiles/tp100.html.>

Agarwal, S. K., Bhatnagar, U. \& Rajesh, N. (2004). Acute and genotoxic profile of a dimeric impurity of cefotaxime. International Journal of Toxicology, Vol.23, pp. 41-45.

Ashby, J. (1990). Determination of the genotoxic status of a chemical. Mutation Research,Vol. 248, pp. 221-231.

Ashby, J. \& Tennant, R. W. (1991). Definitive relationships among chemical structure, carcinogenicity and mutagenicity for 301 chemicals tested by the U.S. NTP. Mutation Research, Vol. 257, pp. 229-306.

Bai, L., Sun, M., An, J., Liu, D. Q., Chen, T. K. \& Kord, A. S. (2010). Enhancing the detection sensitivity of trace analysis of pharmaceutical genotoxic impurities by chemical derivatization and coordination ion spray-mass spectrometry. Journal of Chromatography A,Vol. 1217, pp. 302-306.

Bempong, D. K., Honigberg, I. L. \& Meltzero, N. M. (1993). Separation of 13-cis and all-trans retinoic acid and their photodegradation products using capillary zone electrophoresis and micellar electrokinetic chromatography (MEC). Journal of Pharmaceutical and Biomedical Analysis, Vol. 11, No. 9, pp. 829-833.

Benigni, R., Conti, L., Crebelli, R., Rodomonte, A. \& Vari, M. R. (2005). Simple and a,bunsaturated aldehydes: correct prediction of genotoxic activity through structureactivity relationship models. Environmental and Molecular Mutagenesis, Vol. 46, pp. 268-280. 
Bercu, J. P., Morton, S. M., Deahl, J. T., Gombar, V. K., Callis, C. M. \& Van Lier, R. B. L. (2010). In silico approaches to predicting cancer potency for risk assessment of genotoxic impurities in drug substances. Regulatory Toxicology and Pharmacology, Vol. 57, pp. 300-306.

Bercu, J. P., Dobo, K. L., Gocke E. \& McGovern, T. J. (2009). Overview of genotoxic impurities in pharmaceutical development. International Journal of Toxicology, Vol. 28, pp. 468-478.

Borman, P. J., Chatfield, M. J., Crowley, E. L., Eckers, C., Elder, D. P., Francey, S. W., Laures, A. M. F. \& Wolf, J. C. (2008). Development, validation and transfer into a factory environment of a liquid chromatography tandem mass spectrometry assay for the highly neurotoxic impurity FMTP (4-(4 fluorophenyl)-1-methyl-1,2,3,6tetrahydropyridine) in paroxetine active pharmaceutical ingredient (API). Journal of Pharmaceutical and Biomedical Analysis, Vol. 48, pp. 1082-1089.

Carlin, A., Gregory, N. \& Simmons, J. (1998). Stability of isoniazid in isoniazid syrup: formation of hydrazine. Journal of Pharmaceutical and Biomedical Analysis, Vol. 17, pp. 885-890.

Cimarosti, Z., Bravo, F., Stonestreet, P., Tinazzi, F., Vecchi, O. \& Camurri, G. (2010). Application of quality by design principles to support development of a control strategy for the control of genotoxic impurities in the manufacturing process of a drug substance. Organic Process Research and Development, Vol. 14, pp. 993-998.

Col'on, I. \& Richoll, S. M. (2005). Determination of methyl and ethyl esters of methanesulfonic, benzenesulfonic and p-toluenesulfonic acids in active pharmaceutical ingredients by solid-phase microextraction (SPME) coupled to GC/SIM-MS. Journal of Pharmaceutical and Biomedical Analysis, Vol. 39, pp. 477-485.

Cunningham, A. R., Rosenkranz, H. S., Zhang, Y. P. \& Klopman, G. (1998). Identification of 'genotoxic' and 'non-genotoxic' alerts for cancer in mice: the carcinogenic potency database. Mutation Research, Vol. 398, pp. 1-17.

David, F., Jacq, K., Sandra, P., Baker, A. \& Klee, M. S. (2010). Analysis of potential genotoxic impurities in pharmaceuticals by two-dimensional gas chromatography with Deans switching and independent column temperature control using a lowthermal-mass oven module. Analytical and Bioanalytical Chemistry, Vol. 396, pp. 1291-1300.

Dearfield, K. L., Cimino, M. C., McCarroll, N. E., Mauer, I. \& Valcovic, L. R. (2002). Genotoxicity risk assessment: a proposed classification strategy. Mutation Research Genetic Toxicology and Environmental Mutagenesis, Vol. 521, pp. 121-135.

Dobo, K. L., Greene, N., Cyr, M. O., Caron, S. \& Ku, W. W. (2006). The application of structure-based assessment to support safety and chemistry diligence to manage genotoxic impurities in active pharmaceutical ingredients during drug development. Regulatory Toxicology and Pharmacology, Vol. 44, pp. 282-293.

Eichenbaum, G., Johnson, M., Kirkland, D., O'Neill, P., Stellar, S., Bielawne, J., DeWire, R. \& Areia, D. (2009). Assessment of the genotoxic and carcinogenic risks of pnitrophenol when it is present as an impurity in a drug product. Regulatory Toxicology and Pharmacology, Vol. 55, pp. 33-42. 
Elder, D. P., Delaney, E., Teasdale, A., Eyley, S., Reif, V. D., Jacq, K., Facchine, K. L., Oestrich, R. S., Sandra, P. \& David, F. (2010a). The utility of sulfonate salts in drug development. Journal of Pharmaceutical Sciences, Vol. 99, pp. 2948-2961.

Elder, D. P., Snodin D., \& Teasdale, A. (2010b). Analytical approaches for the detection of epoxides and hydroperoxides in active pharmaceutical ingredients, drug products and herbals. Journal of Pharmaceutical and Biomedical Analysis, Vol. 51, pp. 1015-1023.

Elder, D. P., Snodin, D. \& Teasdale, A. (2010c). Control and analysis of hydrazine, hydrazides and hydrazones-Genotoxic impurities in active pharmaceutical ingredients (APIs) and drug products. Journal of Pharmaceutical and Biomedical Analysis .

Elder, D. P. \& Snodin, D. J. (2009). Drug substances presented as sulfonic acid salts: Overview of utility, safety and regulation. Journal of Pharmacy and Pharmacology,Vol. 61, pp. 269-278.

Elder, D. P., Lipczynski, A. M., \& Teasdale, A. (2008a). Control and analysis of alkyl and benzyl halides and other related reactive organohalides as potential genotoxic impurities in active pharmaceutical ingredients (APIs). Journal of Pharmaceutical and Biomedical Analysis, Vol. 48, pp. 497-507.

Elder, D. P., Teasdale, A. \& Lipczinsky, A. M. (2008b). Control and analysis of alkyl esters of alkyl and aryl sulfonic acids in novel active pharmaceutical ingredients (APIs). Journal of Pharmaceutical and Biomedical Analysis, Vol. 46, pp. 1-8.

EMEA/CHMP. (June 2006). Guideline on the limits of genotoxic impurities, In: European Medicines Agency, 20 January 2011, Available from: <http://www.emea.eu.int.>

Flora, S. D., Zanacchi, P., Camoirano, A., Bennicelli, C. \& Badolati, G. S. (1984). Genotoxic activity and potency of 135 compounds in the Ames reversion test and in a bacterial DNA-repair test. Mutation Research, Vol. 133, pp. 161-198.

Garg, A., Solas, D. W., Takahashi L. H. \& Cassella, J. V. (2010). Forced degradation of fentanyl: Identification and analysis of impurities and degradants. Journal of Pharmaceutical and Biomedical Analysis, Vol. 53, pp. 325-334.

Glatt, H., Jung, R. \& Oesch, F. (1983) Bacterial mutagenicity investigation of epoxides: drugs, drug metabolites, steroids and pesticides. Mutation Research, Vol. 11, pp. 99-118.

Gocke, E., Bürgin, H., Müller, L. \& Pfister, T. (2009a). Literature review on the genotoxicity, reproductive toxicity, and carcinogenicity of ethyl methanesulfonate. Toxicology Letters, Vol. 190, pp. 254-265.

Gocke, E., Müller, L. \& Pfister T. (2009b). EMS in Viracept-Initial ('traditional') assessment of risk to patients based on linear dose response relations. Toxicology Letters, Vol. 190, pp. 266-270.

Guo, F. Q., Liang, Y. Z., Xu, C. J. \& Huang, L. F. (2003). Determination of the volatile chemical constituents of Notoptergium incium by gas chromatography-mass spectrometry and iterative or non-iterative chemometrics resolution methods. Journal of Chromatography A, Vol. 1016, pp. 99-110.

Hajikarimian, Y., Yeo, S., Ryan, R. W., Levett, P., Stoneley, C. \& Singh, P. (2010). Investigation into the formation of the genotoxic impurity ethyl besylate in the final step manufacturing process of UK-369,003-26, a novel PDE5 inhibitor. Organic Process Research and Development, Vol. 14, pp. 1027-1031. 
Hansen S. H. \& Sheribah Z.A. (2005). Comparison of CZE, MEKC, MEEKC and non-aqueous capillary electrophoresis for the determination of impurities in bromazepam. Journal of Pharmaceutical and Biomedical Analysis, Vol. 39, pp. 322-327.

Hmelnickis, J., Pugovics, O., Kazoka, H., Viksna, A., Susinskis, I. \& Kokums, K. (2008). Application of hydrophilic interaction chromatography for simultaneous separation of six impurities of mildronate substance. Journal of Pharmaceutical and Biomedical Analysis, Vol. 48, pp. 649-656.

Hude, W., Seelbach, A. \& Basler, A. (2010). Epoxides: Comparison of the induction of SOS repair in Escherichia coli PQ37 and the bacterial mutagenicity in the Ames test. Mutation Research, Vol. 231, pp. 205-218.

ICH. (March 2008). Guidance on genotoxicity testing and data interpretation for pharmaceuticals intended for human use S2(R1), In: International conference on harmonisation of technical requirements for registration of pharmaceuticals for human use, accessed on 20 January 2011, Available from: <http://www.ich.org.>

ICH. (October 2006). Impurities in new drug substances Q3A(R2). In: International conference on harmonisation of technical requirements for registration of pharmaceuticals for human use, Accesssed on 20 January 2011, Available from: <http://www.ich.org.>

ICH. (July 1997). Genotoxicity : A standard battery for genotoxicity testing of pharmaceuticals S2B. In: International conference on harmonisation of technical requirements for registration of pharmaceuticals for human use, Accessed on 20 January 2011, Available from: <http://www.ich.org.>

Jacobson-Kram, D. \& McGovern, T. (2007). Toxicological overview of impurities in pharmaceutical products. Advanced Drug Delivery Reviews, Vol. 59, pp. 38-42.

Jindal, K. C., Chaudhary, R. S., Gangwal, S. S., Singla, A. K. \& Khanna, S. (1994). Highperformance thin-layer chromatographic method for monitoring degradation products of rifampicin in drug excipient interaction studies. Journal of Chromatography A, Vol. 685, pp. 195-199.

Jouyban, A. \& Kenndler, E. (2008). Review: Impurity analysis of pharmaceuticals using capillary electromigration methods. Electrophoresis, Vol. 29, pp. 3531-3551.

Klick, S. (1995). Evaluation of different injection techniques in the gas chromatographic determination of thermolabile trace impurities in a drug substance. Journal of Pharmaceutical and Biomedical Analysis, Vol. 13, pp. 563-566.

Kong, L., Li, X., Zou, H., Wang, H., Mao, X., Zhang, Q. \& Ni, J. (2001). Analysis of terpene compounds in Cimicifuga foetida $\mathrm{L}$. by reversed-phase high-performance liquid chromatography with evaporative light scattering detection. Journal of Chromatography A, Vol. 936, pp. 111-118.

Kruhlak, N. L., Contrera, J. F., Benz, R. D. \& Matthews, E. J. (2007). Progress in QSAR toxicity screening of pharmaceutical impurities and other FDA regulated products. Advanced Drug Delivery Reviews, Vol. 59, pp. 43-55.

Lacroix, P. M., Curran, N. M. \& Lovering, E. G. (1992). Nadolol: High-pressure liquid chromatographic methods for assay, racemate composition and related compounds. Journal of Pharmaceutical \& Biomedical Analysis, Vol. 10, pp. 917-924.

Liu, D. Q., Sun, M. \& Kord, A. S. (2010). Recent advances in trace analysis of pharmaceutical genotoxic impurities. Journal of Pharmaceutical and Biomedical Analysis, Vol. 51, pp. 999-1014. 
Liu, D. Q., Chen, T. K., McGuir, M. A. \& Kord, A. S. (2009). Analytical control of genotoxic impurities in the pazopanib hydrochloride manufacturing process. Journal of Pharmaceutical and Biomedical Analysis, Vol. 50, pp. 144-150.

Liu, J., Zhou, W., You, T., Li, F., Wang, E. \& Dong, S. (1996). Detection of hydrazine, methylhydrazine, and isoniazid by capillary electrophoresis with a palladiummodified microdisk array electrode. Analytical Chemistry, Vol. 68, pp. 3350-3353.

Matsui, F., Robertson, D. L. \& Lovering, E. G. (1983). Determination of hydrazine in pharmaceuticals 111: Hydralazine and Isoniazid Using GLC. Journal of Pharmaceutical Sciences, Vol. 72, pp. 948-951.

Mahuzier, P. E., Clark, B. J., Crumpton, A. J. \& Altria, K. D. (2001). Quantitative microemulsion electrokinetic capillary chromatography analysis of formulated drug products. Journal of Separation Science, Vol. 24, pp. 784-788.

McGovern, T. \& Jacobson-Kram, D. (2006). Regulation of genotoxic and carcinogenic impurities in drug substances and products. Trends in Analytical Chemistry, Vol. 25, pp. 790-795.

Müller, L., Mauthe, R. J., Riley, C. M. et al. (2006). A rationale for determining, testing, and controlling specific impurities in pharmaceuticals that possess potential for genotoxicity. Regulatory Toxicology and Pharmacology, Vol. 44, pp. 198-211.

Nassar, M. N., Cucolo, M. \& Miller, S. A. (2009). Ethyl methanesulphonate in a parenteral formulation of BMS-214662 mesylate, a selective farnesyltransferase inhibitor: Formation and rate of hydrolysis. Pharmaceutical Development and Thecnology, Vol. 14, pp. 672-677.

Petkovska, R., Cornett, C. \& Dimitrovska, A. (2008). Development and validation of rapid resolution RP-HPLC method for simultaneous determination of atorvastatin and related compounds by use of chemometrics. Analytical Letters, Vol. 41, pp. 992-1009.

Ramakrishna, K., Raman, N. V. V. S. S., Narayana Rao, K. M. V., Prasad, A.V. S. S. \& Subhaschander Reddy, K. (2008). Development and validation of GC-MS method for the determination of methyl methanesulfonate and ethyl methanesulfonate in imatinib mesylate. Journal of Pharmaceutical and Biomedical Analysis, Vol. 46, pp. 780783.

Raman, N. V. V. S. S., Reddy, K. R., Prasad, A.V.S.S. \& Ramakrishna, K. (2008). Development and validation of RP-HPLC method for the determination of genotoxic alkyl benzenesulfonates in amlodipine besylate. Journal of Pharmaceutical and Biomedical Analysis, Vol. 48, pp. 227-230.

Rao, B. M., Sangaraju, S., Srinivasu, M. K., Madhavan, P., Devi, L. M., Kumar, R. P., Chandrasekhar, K. B., Arpitha, C. \& Balaji, T. S. (2006). Development and validation of a specific stability indicating high performance liquid chromatographic method for rizatriptan benzoate. Journal of Pharmaceutical and Biomedical Analysis, Vol. 41, pp. 1146-1151.

Robinson, D. I. (2010). Control of genotoxic impurities in active pharmaceutical ingredients: A review and perspective. Organic Process Research and Development, Vol. 14, pp. 946-959.

Sass, S. \& Stutz, M. H. (1981). Thin-layer chromatography of some sulfur and nitrogen mustards. Journal of Chromatography A, Vol. 213, pp. 173-176. 
Sawatari, K., Nakanishi, Y. \& Matsushima, T. (2001). Relationships between chemical structures and mutagenicity: a preliminary survey for a database of mutagenicity test results of new work place chemicals. Industrial Health, Vol. 39,pp. 341-345.

Schülé, A., Ates, C., Palacio, M., Stofferis, J., Delatinne, J.-P., Martin, B. \& Lloyd, S. (2010). Monitoring and control of genotoxic impurity acetamide in the synthesis of zaurategrast sulfate. Organic Process Research and Development, Vol. 14, pp. 10081014.

Snodin, D. J. (2010). Genotoxic impurities: From structural alerts to qualification. Organic Process Research and Development, Vol. 14, pp. 960-976.

Snodin, D. J. (2006). Residues of genotoxic alkyl mesylates in mesylate salt drug substances: real or imaginary problems? Regulatory Toxicology and Pharmacology, Vol. 45, pp. 79-90.

Sobol, Z., Engel, M. E., Rubitski, E., Ku, W. W., Aubrecht, J. \& Schiestl, R. H. (2007). Genotoxicity profiles of common alkyl halides and esters with alkylating activity. Mutation Research - Genetic Toxicology and Environmental Mutagenesis, Vol. 633, pp. 80-94.

Sun, M., Bai, L., Terfloth, G. J., Liu, D. Q. \& Kord, A. S. (2010). Matrix deactivation: A general approach to improve stability of unstable and reactive pharmaceutical genotoxic impurities for trace analysis. Journal of Pharmaceutical and Biomedical Analysis, Vol. 52, pp. 30-36.

Tafazoli, M., Baeten, A., Geerlings, P. \& Kirsch-Volders, M. (1998). In vitro mutagenicity and genotoxicity study of a number of short-chain chlorinated hydrocarbons using the micronucleus test and the alkaline single cell gel electrophoresis technique (Comet assay) in human lymphocytes: a structure-activity relationship (QSAR) analysis of the genotoxic and cytotoxic potential. Mutagenes, Vol. 13, pp. 115-126.

Teasdale, A., Eyley, S. C., Delaney, E., Jacq, K., Taylor-Worth, K., Lipczynski, A., Reif, V., Elder, D. P., Facchine, K. L., Golec, S., Oestrich, R. S., Sandra, P. \& David, F. (2009). Mechanism and processing parameters affecting the formation of methyl methanesulfonate from methanol and methanesulfonic acid: an illustrative example for sulfonate ester impurity formation. Organic Process Research and Development, Vol. 13, pp. 429-433.

Valerio, L. G. (2009). In silico toxicology for the pharmaceutical sciences. Toxicology and Applied Pharmacology, Vol. 241, pp. 356-370.

Valvo, L., Alimenti, R., Alimonti, S., Raimondi, S., Foglietta, F. \& Campana, F. (1997). Development and validation of a liquid chromatographic method for the determination of related substances in verapamil hydrochloride. Journal of Pharmaceutical and Biomedical Analysis, Vol. 15, pp. 989-996.

Vijayan, M., Deecaraman, M. \& Pudupalayam, K. T. (2007). In vitro genotoxicity of piperacillin impurity-A. African Journal of Biotechnology, Vol. 6, pp. 2074-2077.

Wade, D. R., Airy, S. C. \& Sinsheimer J. E. (1978). Mutagenecity of aliphatic epoxides. Mutation Research, Vol. 58, pp. 217-223.

Yasueda, S., Higashiyama, M., Shirasaki, Y., Inada, K. \& Ohtori, A. (2004). An HPLC method to evaluate purity of a steroidal drug, loteprednol etabonate. Journal of Pharmaceutical and Biomedical Analysis, Vol. 36, pp. 309-316. 
Yu, Y., Huang, T., Yang, B., Liu, X. \& Duan, G. (2007). Development of gas chromatographymass spectrometry with microwave distillation and simultaneous solid-phase microextraction for rapid determination of volatile constituents in ginger. Journal of Pharmaceutical and Biomedical Analysis, Vol. 43, pp. 24-31. 


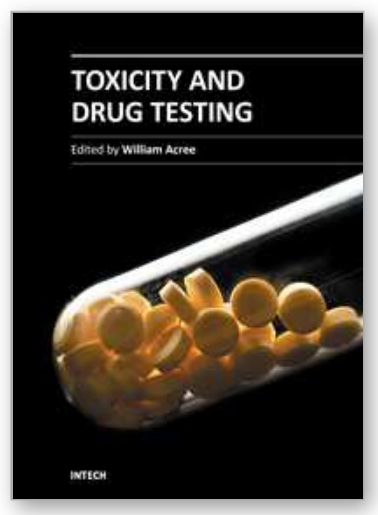

\author{
Toxicity and Drug Testing \\ Edited by Prof. Bill Acree
}

ISBN 978-953-51-0004-1

Hard cover, 528 pages

Publisher InTech

Published online 10, February, 2012

Published in print edition February, 2012

Modern drug design and testing involves experimental in vivo and in vitro measurement of the drug candidate's ADMET (adsorption, distribution, metabolism, elimination and toxicity) properties in the early stages of drug discovery. Only a small percentage of the proposed drug candidates receive government approval and reach the market place. Unfavorable pharmacokinetic properties, poor bioavailability and efficacy, low solubility, adverse side effects and toxicity concerns account for many of the drug failures encountered in the pharmaceutical industry. Authors from several countries have contributed chapters detailing regulatory policies, pharmaceutical concerns and clinical practices in their respective countries with the expectation that the open exchange of scientific results and ideas presented in this book will lead to improved pharmaceutical products.

\title{
How to reference
}

In order to correctly reference this scholarly work, feel free to copy and paste the following:

Abolghasem Jouyban and Hamed Parsa (2012). Genotoxic Impurities in Pharmaceuticals, Toxicity and Drug Testing, Prof. Bill Acree (Ed.), ISBN: 978-953-51-0004-1, InTech, Available from: http://www.intechopen.com/books/toxicity-and-drug-testing/genotoxic-impurities-in-pharmaceuticals

\section{INTECH}

open science | open minds

\section{InTech Europe}

University Campus STeP Ri

Slavka Krautzeka 83/A

51000 Rijeka, Croatia

Phone: +385 (51) 770447

Fax: +385 (51) 686166

www.intechopen.com

\section{InTech China}

Unit 405, Office Block, Hotel Equatorial Shanghai

No.65, Yan An Road (West), Shanghai, 200040, China

中国上海市延安西路65号上海国际贵都大饭店办公楼 405 单元

Phone: +86-21-62489820

Fax: +86-21-62489821 
(C) 2012 The Author(s). Licensee IntechOpen. This is an open access article distributed under the terms of the Creative Commons Attribution 3.0 License, which permits unrestricted use, distribution, and reproduction in any medium, provided the original work is properly cited. 